\title{
ELS IMPOSTOS SOBRE LA RENDA A CATALUNYA: REDELMES, ONZENS I SIMILARS ${ }^{1}$
}

\author{
JORDI MORELLÓ I BAGET \\ Institució Milà $i$ Fontanals \\ (CSIC, Barcelona)
}

\section{SUMARI}

1. Preàmbul: els impostos sobre la renda com a nova via de punció fiscal.- 2. Justificació de l'impost.- 3. Difusió geogràfica.- 4. Naturalesa de l'impost.- 5. Subjectes fiscals i àmbit d'aplicació; 6. Taxes aplicades.- 7. Matèria imposable.- 8. Forma de percepció: trets generals.- 9. Forma de gestió.- 10. Consideracions finals.

\section{PREÀMBUL: ELS IMPOSTOS SOBRE LA RENDA COM A NOVA VIA DE PUNCIÓ FISCAL}

En l'estudi de la fiscalitat municipal, una tasca encara no del tot finalitzada és completar i aprofundir en el coneixement de la tècnica fiscal,

\footnotetext{
'Aquest treball té el seu origen en l'exposició realitzada en el Seminari que es va celebrar a Sevilla (del 12 al 14 d'abril de 1997) sobre "Formas y técnicas del establecimiento y percepción de los impuestos en las ciudades bajomedievales (Francia meridional, Cataluña, Valencia y Castilla)". Agraïm al col.lega Pere Verdés per la seva desinteressada col.laboració en proporcionar-nos diverses informacions sobre el tema en qüestió, i amb qui hem pogut intercanviar impressions sobre el material recollit. Amb tot, els desencerts del treball seran únicament de responsabilitat nostra. Una versió resumida d'aquest treball (modificat en alguns aspectes) es troba a J. MoRELLó, La perception de l'impôt sur le revenu en Catalogne: "redelmes", "onzens" et similaires, dins D. MENJOT / M. SÁNCHEZ (coord.), La fiscalité des villes au Moyen Age (France méridionale, Catalogne et Castille), vol. 2, en premsa. Respecte de les sigles utilitzades, vegeu l'Annex, apartat 2.
}

"Anuario de Estudios Medievales", 27 (1997) 
pas previ i ineludible per a poder comprendre millor la incidència d'aquella fiscalitat sobre la col-lectivitat i els diferents grups socials i sobre els mateixos individus ${ }^{2}$. Fins no fa molt, les úniques fonts (o instruments) de tipus fiscal que es prenien en consideració eren dues: les talles, per mitjà de les quals es gravava a les persones normalment prenent de base els seus béns patrimonials, i les imposicions o cises, que gravaven les transaccions de productes de consum i de mercaderies. Semblava que aquests dos instruments, en tant que exponents d'una fiscalitat directa i indirecta (d'acord amb la divisió clàssica), eren representatius de dues úniques opcions (dues només) de l'activitat fiscal generada en el si de cada municipi. Tanmateix, les investigacions dutes a terme en els darrers anys sobre alguns municipis catalans posen de manifest formes de punció molt variades (sobre la forma concreta d'aplicar aquelles talles i aquelles imposicions) a més d'evidenciar la necessitat d'incorporar un nou element al binomi enunciat. El fet és que, si volem tenir una imatge més completa del que representà la fiscalitat en els municipis catalans, caldrà tenir en compte un tercer instrument fiscal, el qual, com intentarem mostrar aquí, presenta unes característiques pròpies que el fan un impost no assimilable ben bé a les talles tradicionals ni tampoc a les imposicions. Podem anomenar-lo impost sobre la renda (en terminologia actual, naturalment, ja que a l'època s'hi feia al-lusió amb diferents noms: "redelmes", "onzens", "setzens", etc.). A diferència de les talles $\mathrm{i}$ també de les imposicions, que tenen el seu origen abans del segle XIV, l'impost del qual parlarem ara hauria tingut les seves primeres manifestacions més tardanament, assolint un moment de màxima expansió al llarg de la segona meitat del segle XIV, com veurem més endavant. La raó d'aquesta expansió té unes causes bastant evidents, ja que tot plegat coincideix amb un període de màxima ebullició fiscal, si se'n permet l'expressió. Contínuament pressionats per les fortes demandes fiscals de la Corona -o encara per necessitats d'altra índole-, els municipis van haver de fer un esforç considerable per augmentar les seves fonts d'ingressos, tant les fiscals com les no fiscals; almenys en alguns casos, arribà un punt en què l'ingressat per mitjà de les imposicions i les talles no seria del tot suficient per fer front a

\footnotetext{
${ }^{2}$ Les tècniques fiscals emprades produeixen al seu torn unes fonts específiques. Precisament, l'estudi de les fonts fiscals i financeres fou l'objectiu d'un seminari celebrat a Barcelona el 1995 , origen de la publicació realitzada un any després a D. MENJOT / M. SÁNCHEZ (coord.), La fiscalité des villes au Moyen Âge (France méridionale, Catalogne et Castille).1.Etude des sources, Toulouse, Éditions Privat, 1996.
} 
tots els deutes contrets, sobretot els derivats dels censals (rendes perpetuals) i violaris (rendes vitalícies) que en bona part foren creats per satisfer aquelles demandes ${ }^{3}$. Una forma de fer front a aquesta situació fou, doncs, diversificar els ingressos i cercar noves vies de finançament, a banda de crear recàrrecs $i$ noves imposicions o d'incrementar la freqüència en el recurs a la talla (en alguns llocs regularitzada a l'igual que les imposicions) ${ }^{4}$ L'aparició en alguns casos de noves modalitats impositives, a banda de fer possible l'increment del volum del que s'ingressava i de poder destinar els diners obtinguts a cobrir determinades despeses, suposava una forma distinta de gravar un col-lectiu de persones que ja contribuien a les talles i a les imposicions segons la seva fortuna o per la realització d'algunes activitats o pel grau de consum de certs productes bàsics. En aquestes circumstàncies, l'impost que ara ens ocupa (relativament nou en relació amb experiències fiscals anteriors) s'afegiria com a tercera via de punció fiscal a les dues vies tradicionals ja indicades, mentre que altres vegades podia plantejar-se també

\footnotetext{
${ }^{3}$ Que les talles i les imposicions no eren suficients per a cobrir totes les despeses, es fa explícit, per exemple, a Cervera, on, a propòsit d'una concessió obtinguda del rei el 1377, es deia que per tal de pagar els annuals dels censals, les obres de les muralles i altres despeses que s'havien fet per mor del rei o de la pròpia universitat, aquesta estava tan oprimida que ni les imposicions ni les talles podien cobrir aquelles despeses. En aquest moment es plantejava la necessitat d'augmentar les imposicions i d'imposar cert dret sobre diverses vitualles (cereals, verema, safrà $i$ carn), sobre els rèdits de molins $i$ forns, sobre els censals i violaris, sobre els capitals de mercaders, emoluments d'advocats i notaris, i, més en general, sobre qualsevol guany percebut pels habitants d'aquella vila. A precs, doncs, dels dirigents locals, el rei donava permís per augmentar les imposicions juntament amb l'establiment d'aquest "nou dret" (segons el qualificatiu que es dóna al document); ACA, C, reg. 929 , fols. 67 v. -68 r. A nivell local consta que aquell any mateix any es redactaren uns capitols de l'onzè i que es van fer algunes gestions per trobar possibles arrendataris; $\mathrm{cf}$. M. TURULL, La configuració jurídica del municipi baix-medieval. Règim jurídic i fiscalitat a Cervera entre 1182-1430, Barcelona, 1990, p. 524.

${ }^{4} \mathrm{O}$ augmentant també els cànons de les talles esdevingudes regulars. Efectivament, en alguns casos, que sapiguem, les talles es convertiren en un recurs de finançament regular. Així, el pagament de les qüèsties reials (tributs ordinaris imposats per la Corona en el seu domini) fou, sens dubte, determinant perquè algunes viles de reialenc, que no havien obtingut exempció d'aquell tribut, establissin talles -dites precisament qüèsties- amb la finalitat de satisfer el tribut del mateix nom, i esdevenint de caràcter bastant regular, si no anual, des de finals ja del segle XIII. En aquesta qüestió, l'exemple local millor conegut és, sens dubte, Cervera, gràcies a l'obra de M. Turull, La configuració jurídica cit., p. 528 i ss. Amb el temps, i a mesura que es consolidava una estructura financera, el municipi començà a recaptar més de l'estrictamen necessari per a satisfer aquell tribut, amb la qual cosa podia destinar una part de la col.lecta a necessitats pròpies de la vila. Altres viles del Principat (excloses d'aquestes que encara estaven subjectes a les qüèsties) acabarien també per regularitzar la percepció de talles, ja a la segona meitat del segle XIV, que es convertiren en una segona font de finançament ordinària (junt a les imposicions). Pel cas de Valls, aquest pas, d'importants conseqüències fiscals, tingué lloc el 1369; cf. J. MORELLó, El règim municipal de Valls segons un ordinacions del 1369, "Historia et documenta", 1 (1994), pp. 11-39.
} 
com a alternativa a les talles 5 . Ja al segle XV, en algunes localitats (Cervera, Valls) aquest impost arribà a substituir a les talles (en tant que ingressos ordinaris) durant almenys un cert període de temps ${ }^{6}$. En aquest treball, però, ens interessa incidir més que res sobre aspectes fiscals que no pas sobre la incidència financera de l'impost.

Ara bé, mentre que les talles i les imposicions han estat objecte d'alguns estudis específics ${ }^{7}$, en canvi, l'impost en qüestió (onzens i afins) no han tingut fins al moment un tractament monogràfic per part dels estudiosos de temes fiscals, tret d'algunes visions locals ${ }^{8}$. L'objectiu ${ }^{5}$ En el cas de Bagà (1392) es plantejava a la comunitat de veïns què preferien: si
l'establiment d'un "vintè" o d'un "manifest", és a dir, una taxa sobre les collites i guanys o una
talla basada en la declaració de béns; cf. J. SERRA VILARÓ, Baronies de Pinós i Mataplana, vol.
2, Barcelona, 1930, p. 91 . A Blanes i altres localidats del vescomtat de Cabrera s'obtingué la
conformidat del senyor per tal que durant el temps que durés el deè imposat no es paguessin
talles ni qüèsties; cf. J.M Ma PONS GuRI, Llibre de la universitat de la vila de Blanes, Blanes,
1969, p. 125 .

${ }^{6} \mathrm{Pel}$ que fa a Cervera, és aquest un aspecte que està en fase d'estudi per part de Pere Verdés. Pel que fa a Valls, sabem que pels volts del 1425 es començà a recaptar anualment un impost (amb el nom ja de milanar), coincidint amb la desaparició de la talla ordinària (com a tal, des del 1369); això, com molts altres aspectes relacionats amb aquest impost en el marc del Camp de Tarragona, són tractats a la nostra tesi: J. Morelló, Fiscalitat i finances de dues viles del Camp de Tarragona: Reus $i$ Valls durant els segles XIV $i$ XV, Tesi Doctoral inèdita, Univ. de Barcelona, 1998, espec. al cap. 5 de la Primera Part, p. 551 i ss.

${ }^{7} \mathrm{Pel}$ que respecte a l'impost directe, vegeu M. TURULL, La hacienda municipal y la tributación directa en Cataluña durante la Edad Media. Planteamiento general, "Revista de Hacienda Autonómica y Local", XXII/64 (Enero-abril/1992), pp. 9-80, entre altres treballs; o bé treballs més cenyits a l'análisi de les fonts, com J. Morello, Aproximació a les fonts fiscals de la Catalunya baixmedieval: llibres d'estimes, valies $i$ manifests, "Anuario de estudios medievales", XXII (1992), pp. 425-441; Notes sobre el funcionament de la fiscalitat directa a la Baixa Edat Mitjana, "Butlletí de la Societat Catalana d'Estudis Històrics", VI (1995), pp. 6180. Respecte a l'impost indirecte (més enllà del clàssic estudi de J. Broussolle, necessitat d'una revisió en molts aspectes, i de les aportacions realitzades en algunes monografies locals, com la de F. Cortiella, pel cas de Tarragona, o la ja indicada de Max Turull, pel cas de Cervera) podem assenyalar ja algun treball monogràfic, com el de P. VERDÉs, Les imposicions a Cervera durant la segona meitat del s. XIV, dins M. SÁNCHEZ / A. FurIó, Actes del Col.loqui "Corona, Municipis $i$ Fiscalitat a la baixa edat mitjana", IEI, Lleida, 1997, pp. 383-422.

${ }^{8} \mathrm{Hem}$ de recordar que Max Turull exposà ja la singularitat d'aquest impost per al cas de Cervera durant la segona meitat del segle XIV; vegeu M. TURULL, La configuració jurídica cit., pp. 521-26. Actualment, l'estudi i anàlisi d'aquest impost en aquesta localitat ha estat reprès per Pere Verdés. Altres consideracions (en base a la troballa de capítols relatius a aquest impost) es troben en alguns estudis d'història local, com els de Francesc Cortiella (sobre Constantí i Vilaverd), i en articles centrats sobre l'endeutament municipal com és el de Ramon Miró (sobre la baronia de Bellpuig al s. XV), citats tots més avall. Per la part que ens pertoca, vam donar a conèixer la forma de percepció de l'impost en el cas de Valls en base també a la publicació dels capítols d'un onzè, citat també més avall. Si això és el que podem indicar tocant a l'àmbit medievalístic, per a època moderna hi ha diferents estudis que confirmen l'establiment d'impostos del tipus que ens ocupa com a pràctica força corrent; vegeu sobretot G. FELIU, El funcionament del règim senyorial a l'Edat Moderna. L'exemple del Pla d'Urgell, Lleida, 1990, 
principal d'aquest treball, tot i el seu caràcter de provisionalitat, és el de donar a conèixer les principals característiques d'un impost quasi desconegut més enllà del cercle restringit dels especialistes. En aquest moment intentarem donar una primera visió global d'aquest impost a Catalunya a partir de referències documentals diverses, intentant determinar, no sols els trets principals d'aquesta modalitat impositiva, sinó també el moment d'aparició i la seva difusió geogràfica arreu de Catalunya, la seva justificació segons el moment o l'època, així com la forma de percepció i de gestió. Això ha de constituir un primer pas també per poder apreciar, en la mesura del possible, el seu caràcter diferencial en relació amb les dues altres fonts fiscals que ens són millor conegudes.

Abans d'entrar en matèria, creiem convenient d'assenyalar, primer que tot, el tipus de documentació que ha servit de fonament al nostre treball de recerca. Les fonts utilitzades són principalment dues:

1) les concessions o llicències donades a una ciutat, vila o grup de parròquies per a poder recaptar un impost d'aquest tipus. Tal com succeïa amb les concessions per poder collir imposicions, aquestes altres tenien estipulat també un límit temporal, concretitzat en un cert nombre d'anys (o collites anuals) variable en cada cas o circumstància. Per altra banda, se sol indicar quins productes havien de ser gravats, però generalment sense donar gaire detalls sobre la forma de percebre's l'impost";

2) els acords o capítols on s'especifiquen quins productes estaven subjectes a l'impost i de quina forma s'havia de percebre, amb la inclusió

espec. p. 135 i ss.; i altres com E. BADOSA, Endeutament col.lectiu $i$ desaparició de béns comunals a Catalunya a la segona meitat del segle XVIII, "Pedralbes. Revista de Historia Moderna", 10 (1990), pp. 51-66; i P. GIFRÉ, Universitats, fiscalitat de guerra i privilegiats. A propòsit d'algunes universitats empordaneses durant la Guerra de Secesió, Ibídem, 13/I (1993), pp. 561-572. Aquest últim registra a Cadaqués, per exemple, la imposició de 19 quinzens en un període de trenta anys: de 1623 a 1653. Per a Granollers, Dantí es refereix també a la percepció d'algun "trentè dels grans"; cf. J. DANTí, La hisenda municipal com a reflex de la conjuntura econòmica. Un exemple de la Catalunya prelitoral: Granollers $i$ la vallès Oriental als segles XVI $i$ XVII, dins Fiscalitat estatal $i$ hisenda local (ss. XVI-XIX). Funcionament $i$ repercussions locals. VI Jornades d'Estudis Històrics Locals, Palma de Mallorca, 1988, pp. 233244 (p. 235 pel que fa a la cita).

${ }^{9} \mathrm{~A}$ partir de la consulta dels registres de Cancelleria de l'ACA hem trobat sobretot llicències, però també hi ha documentació de tipus processal molt interessant, com la referent al procés mantingut entre el fisc reial $\mathrm{i}$ algunes poblacions del Camp de Tarragona durant els anys finals del segle XIV. Aquesta documentació inclou, en la majoria de casos, una còpia dels capítols establerts a cada localitat tocant a la percepció d'onzens i d'altres drets similars, la qual cosa ens forneix una informació molt preciosa que, d'altra banda, no hem trobat en els corresponents arxius locals, a excepció de Valls. Hom veu necessari de realitzar, en tot cas, una recerca molt més exhaustiva, ja no sols a l'ACA, sinó també en l'àmbit dels arxius locals. 
també de les obligacions que havien d'assumir els collidors (o arrendataris) de l'impost, dos aspectes que no sempre trobem convenientment destriats o que són tractats de forma desigual segons els interessos dels redactors dels capítols. De fet, en alguns casos es posa més l'accent en aquell últim aspecte. Tenint en compte que alguns d'aquests capítols ja han estat publicats, utilitzarem aquí tant aquests com altres inèdits que hem localitzat en alguns arxius, sobretot en el de la Corona d'Aragó ${ }^{10}$.

En aquesta qüestió també resulten molt valuoses les informacions que proporcionen moltes històries locals, ja sigui perquè inclouen referències a concessions o bé dades relatives a col-lectes puntuals d'impostos d'aquest tipus o encara informacions d'altra mena. Gràcies a l'ajuda del nostre col-lega Pere Verdés hem pogut fer un aplec de diverses notícies relatives a un important nombre de poblacions, amb la qual cosa hem elaborat els llistats que conformen l'Apèndix. A partir d'aquestes informacions podem saber quina fou la difusió de l'impost en diverses zones del Principat, segons el que exposarem més endavant. Som conscients que això podrà ser objecte d'ampliació a partir d'altres recerques que es facin amb posterioritat a la publicació d'aquest treball. La continuació de la recerca esdevé necessària, ja sigui per revisar les dades exhumades pels historiadors locals, ja sigui sobretot per fer nous descobriments que permetin ratificar-se en les impressions i plantejaments que donarem ara per ara sobre aquest tipus d'impost, o bé rebutjar-les. De moment, creiem que aquest treball pot ajudar a què els estudiosos, més enllà dels qui estem interessats només per la fiscalitat, coneguin l'existència d'aquest impost i les seves característiques principals.

\footnotetext{
${ }^{10}$ Que sapiguem, publicats hi ha els següents: els de Tàrrega de 1377 (cf. Ll. SARRET, Privilegis de Tàrrega, Tàrrega, 1982, pp. 296-308); els de Constantí de 1381 (cf. F. CorTiElla, Historria de Constantí, Constantí, 1981, pp. 202-206); els de Vilaverd de 1404 (publicats pel mateix autor en la seva Història de Vilaverd, Vilaverd, 1982, pp. 191-193); i els de la baronia de Bellpuig de 1457 (cf. R. Miró, Pagar deutes, posar nous impostos. La riquesa dels insolvents poderosos, "Miscel.lània d'estudis. Economia, vida i societat. El pregoner d'Urgell", n. ${ }^{\circ} 9$, pp. 13-36; el document presentat és, de fet, una concòrdia entre les universitats de la dita baronia i els seus creditors). Uns altres capítols que han estat publicats són els de Valls: J. MORELLó, La problemàtica d'un impost a finals del segle XIV: la imposició de l'onzè a Valls el 1394, "Miscel.lània de Textos Medievals", 8 (1996), pp. 249-282. Algunes de les consideracions del present estudi foren ja breument exposades en aquest treball, encara que cenyint-nos completament a les particularitats del document transcrit.
} 


\section{JUSTIFICACIÓ DE L'IMPOST}

Una de les primeres coses que cal deixar clares és que la percepció d'un impost d'aquest tipus no es podia fer sense tenir una autorizació. A les ciutats o viles de reialenc era el propi monarca, o qualsevol dels seus representants, qui donava l'autorització als dirigents municipals perquè pogués ser percebut. Fora del seu domini, la Corona no intervingué en matèria d'onzens, a no ser que es trobés algun indici d'actuacions que anessin en perjudici dels seus drets privatius (en aquest cas, per imposar multes sobre les localitats considerades infractores) o encara en qüestions concernents als rescats de jurisdiccions que veurem més endavant. En tot cas, mai la Corona considerà aquest impost com una regalia, a diferència, doncs, de les imposicions. De fet, en tant que s'aplicava sobre productes que ja estaven sotmesos al pagament de les rendes senyorials (principalment del delme), era lògic que els representants municipals s'adrecessin al senyor $\mathrm{i}$ no al rei, com és el cas de les viles de senyoriu eclesiàstic o baronial.

Així, doncs, era el senyor, com a possessor del domini directe (i, com a tal, recipiendari dels delmes i altres rendes que gravaven la producció agrària), qui donava el seu consentiment per tal que l'impost pogués ser percebut a les localitats que formaven part de la seva demarcació territorial o senyoriu: per exemple, el 1373, el comte d'Urgell donava autorització a totes les universitats de la seva circumscripció (Balaguer, Agramunt, Àger $i$, de forma general, a totes les localitats del comtat) per a poder imposar un "deè". Semblantment, el 1387 el vescomte de Cabrera atorgava una concessió a favor de les localitats del seu vescomtat. Molt més tardanament, Ramon Folc II de Cardona atorgava un onzè a la baronia de Bellpuig d'Urgell el 1457. Al Camp de Tarragona l'arquebisbe realitzà diverses concessions d'aquest tipus, però sols en aquelles poblacions de les quals era senyor directe ${ }^{11}$. En definitiva, l'atorgament sempre era de la incumbència de qui ostentava el domini directe i no de cap altre.

Per altra banda, quan els municipis decidien establir un impost d'aquest tipus, ho feien sempre amb una finalitat molt concreta. Quasi tots

\footnotetext{
"En efecte, aquestes concessions eren de la incumbència dels titulars de la senyoria directa de cada lloc, ja fos l'arquebisbe (com s'observa a Valls, Santa Maria del Pla, Mont-roig, Tamarit...) o algun altre senyor eclesiàstic, com el cambrer (cas de Reus). Quan la Seu quedava vacant, era el paborde qui, en qualitat de lloctinent de l'arquebisbe, feia tals atorgaments, tal com succeí a Constantí el 1381.
} 
fan referència a la mala situació provocada per l'endeutament censal, un problema, com se sap, que estava força generalitzat entre els municipis catalans. Amb freqüència, la justificació que es donava era el pagament del deute, i més concretament, la seva amortització ${ }^{12}$. De fet, trobem casos en què seria destinat tant a l'amortització com també al pagament de les pensions ${ }^{13}$. Però, de vegades s'invoquen alguns altres motius, com són les despeses de les fortificacions ${ }^{14}$. Amb tot, per a una primera etapa (abans del 1360), i fins que l'impost no fou concebut com un recurs específicament destinat a redimir censals, l'establiment d'aquest impost podia obeir a d'altres motius o circumstàncies.

Les primeres concessions que tenim documentades, pertanyents a les dècades de 1340 i 1350 , s'escauen en l'àmbit del domini reial ${ }^{15}$. No sembla casual, d'altra banda, que el motiu principal que s'invoca per a poder imposar algun tipus de delme sigui precisament el de donar satisfacció a les ajudes promeses a la monarquia, a l'igual que les concessions realitzades a la mateixa època en matèria d'imposicions. Vegem-ne els següents exemples:

\footnotetext{
${ }^{12}$ Els capítols de Tàrrega de 1377 són potser els que millor descriuen la situació que empenyia al municipi a establir un impost d'aquest tipus: "per molts e diverses càrrechs, accidents e fortunes qui e que a la dita Universitat són esdevengudes, axí per passatge de companyes estranyes, com per los murs e valls en la dita vila feyts, com encara per esterilitat del temps passat e penúria e gran carestia, la qual és estada e encara és, la Universitat de la dita vila de Tàrrega se sie haguda de encarregar de molts e diverses censals e violaris, e de molts e diverses deutes, los quals ha haguts a pendre e vendre e manlevar, los quals censals e violaris e altres deutes, per profit e utilitat e restaurament de la dita Universitat e singulars d'aquella, cove que sien treyts e reemuts e pagats, com en altra manera, si los dits censals e violaris e altres deutes no eren reemuts e treyts e pagats, la dita Universitat pogués venir leugerament a despoblació etc."; cf. Ll. SARret, Privilegis de Tàrrega, pp. 296-97.

${ }^{13} \mathrm{~A}$ Riudoms (1386) els arrendataris del "redelme" es comprometien a pagar vàries pensions per un valor global de $2.550 \mathrm{~s}$. anuals durant cinc anys. Per a res s'indica que es tingués intenció de redimir aquestes pensions. Endemés, totes les despeses derivades d'aquests pagaments (encartaments) es posarien a compte dels mateixos arrendataris.

${ }^{14}$ Així es registra a Figueres a propòsit de la concessió de 1392. En canvi, a Moià (1378) la reparació de les muralles era l'únic motiu exposat pel qual es va recórrer a la imposició d'un vintè.

${ }^{15}$ De tota manera, és possible que l'origen fiscal de l'impost pugui ser desplaçat a dates més reculades, ja que tenim notícia a cert "ordonament del saixantè" començat a collir a Perpinyà el 1311; cf. B.-J. ALART, Documents sur la langue catalane des anciens comtés de Roussillon et de Cerdagne, París, 1881, pp. 126-127. Segons l'indicat en nota per l'autor, aquest "seixantè" era establert "sur les revenus des biens-fonds ou de l'industrie", tot i que no és el que es desprèn del text dels documents publicats, que concerneixen a dues crides per les quals s'obligava a la població a contribuir en aquell impost mitjançant declaració de tot allò que hagués estat objecte de compra o de venda. El dubte que tenim és si realment es tracta d'un precedent dels impostos que ara considerem o si ens trobem davant d'un peculiar tipus d'imposició?
} 
el 1345 (29-IX) la universitat de Puigcerdà obtenia dues llicències reials: una per a poder collir imposicions sobre determinats productes (vi, carn) i una altra per a poder imposar per via de talla, quèstia o "redelme" fins a la suma de 200.000 sous. En una i altra llicència s'indica que la universitat estava obligada a la cort reial a causa de la confirmació de certs privilegis ${ }^{16}$. Però, tal com està formulat, no és segur que s'imposés aquell delme. Abans inclús d'aquesta data, registrem una altra concessió donada a una vila del Conflent: es tracta de Cauders, on el rei atorgà una concessió de "redelme" o vintè sobre els fruits i collites, al-legant que això es feia segons ja era costum de fer a les terres del Conflent ("prout similia retrodecimum vel vintenum sunt in dicta terra Confluentis prestari et levari consueta") $)^{17}$. En aquest cas, el motiu era pagar els deutes que aquella universitat havia contret per mitjà de préstecs destinats a cobrir despeses locals. També convé indicar que el recaptador de l'impost havia de donar-ne compte als procuradors reials del Rosselló, amb la qual cosa la monarquia s'assegurava un control més enllà del permís atorgat. Trobem una concessió similar a favor d'un poble rosellonès (Montesquiu) el $1350^{18}$, mentre que una altra concessió del mateix any ens trasllada ja a l'interior del Principat: així, a Vilagrassa, petita població pròxima a Tàrrega, el rei concedia imposicions sobre determinats productes (pa, vi, carn i oli) a més d'un onzè sobre les collites de cereal, verema i safrà, per a un període de tres anys ${ }^{19}$.

A partir de 1350 aquestes autoritzacions reials van estendre's a d'altres localitats del Principat. No obstant això, no sempre podem estar segurs de l'efectiva percepció de l'impost, atés que, com ja hem vist en el cas de Puigcerdà, aquest apareix mencionat com una opció més -entre d'altres- per a pagar els subsidis a la Corona. Així, a Cornellà i Conat, dues localitats situades també al Conflent, es donava llicència el 1358 per a imposar un "redelme", "vintè", "imposició", talles o altres exaccions (a més d'obtenir un permís per a poder vendre censals) amb la finalidat d'aplegar

\footnotetext{
${ }^{16} \mathrm{ACA}, \mathrm{C}$, reg. 878 , fol. 226 v. La llicència relativa a les talles precedeix a la de les imposicions

${ }^{17} \mathrm{ACA}, \mathrm{C}$, reg. 878 , fols. 160 v.-161 r. Datat el 12 de juny.

${ }^{18}$ En aquesta localitat el rei atorgà un "vintè o redelme" per a poder pagar certa quantitat que els pobletans li havien concedit graciosament a compte d'un subsidi; ACA, C, reg. 901, fol. $80 \mathrm{r}$. Aquest privilegi data de l'l d'octubre.

${ }^{19} \mathrm{El}$ motiu resulta ben eloqüent: "cum universitas et singulares dicte ville mole debitorum sint valde oppresi hesitetisque ne propter debita ipsa dicta universitas et eius singulares ad irreparabilem destructionem possent devenire"; ACA, C, reg. 891, fol. $14 \mathrm{r}$.
} 
certa quantitat donada com a auxili al rei ${ }^{20}$; també a les parròquies de la vall de Ribes (1358) es donaven diferents possibilitats per a poder respondre a l'auxili que hom prestà al monarca a causa de la guerra amb Castella. En efecte, en aquest cas es podrien establir imposicions, un vintè, talla o redelme, donant llibertat a les dites parròquies per a prendre opció per una $o$ altra via ${ }^{21}$. Pel que es veu, redelmes i vintens no serien equivalents, però no es donen detalls sobre la forma d'aplicació d'aquests drets; l'únic que de moment es pot dir és que eren exaccions diferenciades de les imposicions $\mathrm{i}$ de les talles ${ }^{22}$. Seguint l'ordre cronològic d'altres concessions que tenim documentades, tornem a trobar Puigcerdà com a vila beneficiària (l'any 1361) d'un redelme per raó de les despeses de muralles i també - segons s'indica - per a redimir les imposicions i les ajudes imposades a la dita vila, i encara per altres finalitats no especificades. En aquest cas s'imposaria un redelme d'esplets, fruits, rèdits e guanys, o sia, sobre les collites, fruits, rendes i guanys, encara que sols duraria 1 o 2 anys $^{23}$. En altres concessions no s'assenyalen límits temporals, però podem pensar que el temps estaria condicionat a la liquidació de totes les despeses ocasionades per l'auxili prestat. Del que no hi ha cap dubte és que moltes vegades els deutes als quals es fa referència provenien de subsidis realitzats a la Corona o també per l'obtenció o ratificació de privilegis ${ }^{24}$.

Tractant-se, com hem vist, de concessions reials, hi ha la hipòtesi de què les viles reials haguessin estat les primeres, precisament, en permetre la difusió i generalització d'aquest impost. El fet tindria a veure també amb la major pressió fiscal que, segons semblen mostrar els estudis realitzats fins

\footnotetext{
${ }^{20} \mathrm{ACA}, \mathrm{C}$, reg. 900 , fol. $97 \mathrm{v}$.

${ }^{21} \mathrm{ACA}, \mathrm{C}$, reg. 900, fol. 135 r. Les parròquies citades són Queralbs, Pardines, Ribes, Planols, Campellos, Ventola, Brugaria i Fustinyà.

${ }^{22}$ En la susdita concessió a les parròquies de la vall de Ribes s'esmenten els béns mobles i immobles com a base d'imposició dels distints drets mencionats.

${ }^{23} \mathrm{ACA}, \mathrm{C}$, reg. 906, fol. 141 r.-v. (datat el 19 de desembre).

${ }^{24} \mathrm{Per}$ exemple, el 1376, a les ja mencionades parròquies de la vall de Ribes s'imposava una altra vegada (si és que ja s'havia posat en pràctica a tenor de la concessió de 1358) un nou "redelme" (o vintè) durant 10 anys, cosa que havia de servir per a pagar els deutes contrets a compte de certs privilegis atorgats pel mateix rei; ACA, C, reg. 1683, fol. 43 r. També el 1376 tenim constància d'una concessió donada per l'infant Joan a la parròquia de Calonge, tant d'imposicions com d'un delme (deè), que estarien vigents fins a liquidar els deutes contrets per via de censals i violaris, els quals foren creats al seu torn per a pagar les ajudes realitzades a les guerres contra Gènova i Castella; ACA, C, reg. 1681, fols. 169 r.-170 r.
} 
al moment, van haver de soportar durant les décades centrals del segle $\mathrm{XIV}^{25}$. És possible, doncs, que l'impost es difongués primer a les viles reials i passés finalment a la resta del Principat. Per això caldria veure també si altres llocs o viles que no formaven part del reialenc utilitzaven procediments similars per aquesta mateixa època, a mitjan segle XIV.

Per primera vegada en unes Corts - les de Barcelona de 1365-, en el marc encara de la guerra amb Castella, les ciutats i viles del braç reial demanaren a la Corona de poder recaptar durant tres anys una onzena part de totes les rendes $\mathrm{i}$ altres coses (fruits, guanys $e$ salaris e loguers) qualificant aquesta prestació de "redelme" o també com a "onzè"26. Però, segons sembla, tal disposició va quedar sense efecte. Un any després sabem que Cervera, per decisió dels seus dirigents locals, començà a imposar un delme seguint l'exemple de Lleida ${ }^{27}$; però no tenim constància fins al moment de què altres viles (fora del reialenc) adoptessin el mateix procediment.

Sens dubte, fou a partir de la dècada de 1370 , i pel que resta de segle, quan tingué lloc la gran expansió de l'impost, normalment concebut com un recurs destinat al pagament del deute municipal, encara que fos això generat en bona part per les demandes de la monarquia. En efecte, localitzem redelmes i altres delmes, ja no sols a les viles reials, sinó també en altres d'àmbit senyorial. El pagament dels deutes és de bon tros el motiu que s'invoca amb més freqüència en aquestes concessions, per la qual cosa resultaria enutjós citar exemples. Això no exclou que altres vegades fos

\footnotetext{
${ }^{25}$ Sobre aquesta qüestió, vegeu M. SÁNCHEZ, La fiscalidad real en Catalunya (segle XIV), "Anuario de estudios medievales", 22 (1992, pp. $341-376$ (en concret, pp. 370-371); i, del mateix autor, El naixement de la fiscalitat d'Estat a Catalunya (segles XII-XIV), Girona/Vic, 1995, pp. 123-125.

${ }^{26}$ Aquest impost no s'havia de pagar de donacions, herències, dots i aixovars. D'un altre costat, quedaven eximits tots aquells que prestessin serveis militars personalment. Els representants del dit braç demanaren expressament que per mitjà d'aquest impost es pagués to el que es devia als canvistes, així com altres despeses ja fetes per les Diputacions en anteriors assemblees; cf. Cortes de los antiguos reinos de la Corona de Aragón, t. II, Madrid, 1899, pp. 354-55. S'hi refereix M. FIBLA, Les Corts de Tortosa i Barcelona (1365). Recapte del donatiu, "Cuadernos de Historia Económica de Catalunya", XIX (1978), pp. 97-130 (p. 98 respecte a la cita).

${ }^{27}$ Constitueix, de fet, la primera notícia que tenim sobre l'aplicació d'un impost d'aquest tipus en aquella vila; cf. M. TURULL, La configuració jurídica cit., p. 523. Respecte a l'onzè establert a Lleida, vegeu l'indicat en el darrer apartat tocant a l'oposició d'alguns sectors socials.
} 
autoritzat per a necessitats d'altra mena ${ }^{28}$. Un cas especial és quan s'invoca el pagament de les redempcions jurisdiccionals, tal i com ja anotava la doctora Ferrer en el seu conegut treball sobre les alienacions del patrimoni reial durant l'època del rei Martí $\mathrm{I}^{29}$. Tal procediment seria, com deia la mateixa historiadora, el que millor s'ajustava a les conveniències dels petits municipis rurals. En efecte, si passem revista a les llicències donades per la Corona on es fa explícita aquesta problemàtica, sols trobem localitats de poca entitat ${ }^{30}$. Ara bé, si tenim en compte que la principal despesa que ocasionava l'intent (per part de la població que havia estat alienada) de

\footnotetext{
${ }^{28} \mathrm{Com}$ en tot, hi ha algunes excepcions. El 1378, l'infant Joan concedí a la vila de Moià un vintè per a poder reparar les muralles, potser perquè la vila ja estava agobiada per altres despeses o obligacions envers la Corona: "per tal com no havien diners, segons que digueren, de què la dita perfecció, reparació e preament del dit mur poguessen fer, e com havien, d'altra part, a pagar, segons que digueren, questes, cenes e altres quantitats de peccunia per rahó de les profertes qui són stades fetes al senyor rei per via de capbreus e de talles"; ACA, C, reg. 1683 , fols. 103 r. $-104 \mathrm{v}$.

${ }^{29}$ Aquesta investigadora anotava el cas d'Agramunt del 1391 (tot i que no es tracta d'una qüestió jurisdiccional) i de Camarasa, on entre 1398 i 1401 es varen fer diverses gestions per a poder pagar la redempció de la jurisdicció en base a un onzè sobre les collites; $\mathrm{cf}$. $\mathrm{M}^{\mathrm{a}}$ T.FERRER MALLOL, El patrimoni reial i la recuperació dels senyorius jurisdiccionals en els estats catalano-aragonesos a la fi del segle XIV, "Anuario de estudios medievales", 7 (1970-71), pp. 351-491 (pp. 398-99 pel que fa a la cita).

${ }^{30}$ Diverses parròquies, com la Roca del Vallès i d'altres (Santa Agnès de Llerona, Orrius, Vilanova i la vall o quadra de Riof, actual Valldarió) obtingueren el 1381 de l'infant Joan la possibilitat de fer talles $\mathrm{i}$ un redelme o altra col.lecta per tal de redimir censals pretextu redemptionis; ACA, C, reg. 1686, fols. 111 v.-112 r. A les parròquies de Sant Martí de Cerdanyola i Sant Iscle de les Feixes se'ls concedí un redelme (1388) per tal de poder recuperar

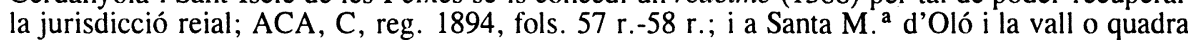
d'Aguiló (pertanyent a la sots-vegueria de Bages) es donà llicència el 1397 per a poder imposar un delme, redelme, quinzè, vintè o altra proporció durant 15 anys; ACA, C, reg. 2166, fols. 68 v. -69 r. (ja amb anterioritat la mateixa localitat havia rebut una concessió similar, encara que a temps indefinit; ACA, C, reg. 2189 , fols. 62 v. -63 v.). El mateix any el rei donà llicència als homes de la Garriga per a poder imposar talles, delmes, redelmes, quints o vintens per a pagar la quantitat de la redempció; ACA, C, reg. 2295 , fols. 15 r.-18 v. segons J. MAURI, Història de la Garriga, vol. I, Barcelona, 1949, p. 150. Ja el 1400 el rei Martí concedia al lloc de Santpedor, prop de Manresa, un privilegi per poder imposar talles o bé delmes, reedelmes, imposicions, quints, vintenes e qualsevulla altres drets, igualment per costejar el preu de redempció de la seva jurisdicció; cf. Mn. ANTON VILA. Notícia històrica de la vila de Sampedor, Manresa, 1898, p. 261. Un cas més tardà es planteja a la parròquia de Premià, on el 1415 el rei Ferran atorgà un redelme per tal de fer front a les despeses d'un plet que la universitat mantenia contra un ciutadà barceloní a compte, si més no, d'una terra pertanyent al patrimoni reial, cosa que també es pot considerar com un intent en certa manera de recuperar drets jurisdiccionals; ACA, C, reg. 2394, fols. 103 v.-104 r. Dos anys més tard el rei Alfons permetia a diverses parròquies, algunes de les quals ja hem esmentat abans (Sant Sadurní de Ribes, Sant Esteve de Vilanova, Sant Andreu d'Orrius, Santa Agnès de Malanyanes i la vall de Riof, de la parròquia de Sant Esteve de Granollers) de poder fer talles o bé redelmes amb la supervisió del batlle general; ACA, C, reg. 1683, fol. 13 r.-v. La llista, ben segur, es podria ampliar amb altres localitats i casos similars.
} 
reintegrar-se al domini reial era, precisament, la venda de censals, i el subsegüent pagament de pensions anuals, no té res d'estrany que una de les fórmules utilitzades fos la imposició de taxes sobre la producció, més encara quan es tractava, com s'ha dit, de petits municipis rurals. Però, insistim, el principal motiu va ser el pagament dels deutes contrets i al marge de les causes que els havien generat ${ }^{31}$. Certament, aquest impost fou concebut fins a cert punt com la panacea que podia solucionar, almenys en part, el problema de l'endeutament censal ${ }^{32}$. I fou precisament a partir de la dècada de 1370 quan es va produir la seva màxima expansió, coincidint amb l'etapa més crítica de les finances municipals a causa dels donatius a la Corona, les caresties de blat i la reforma de les fortificacions urbanes.

Com hem advertit al començament, la possibilitat de percebre aquest impost, per part dels municipis, estava condicionada a l'assignació d'un període de temps limitat i variable en cada cas, rarament superior als 10 anys $^{33}$. No es preveia, en principi, que pogués esdevenir una font de finançament regular, tal com succeí amb les imposicions a tot arreu o també amb les talles en alguns llocs.

\section{DIFUSIÓ GEOGRÀFICA}

A primera vista és indubtable que ens trobem davant un fenomen bastant generalitzat, com es pot veure a partir del mapa adjunt, on indiquem el primer any del qual tenim notícia a l'establiment o percepció d'un impost

\footnotetext{
${ }^{31}$ Algunes poblacions del Camp de Tarragona obtingueren llicències per a poder fer front als deutes contrets a compte del donatiu que s'havia fet a l'arquebisbe quan aquest realitzà la compra dels drets jurisdiccionals que la Corona tenia en aquell territori (1391); tenim constància d'això a la baronia d'Alforja i també a Vinyols i els Arcs. Quelcom similar es podria dir del delme imposat a les baronies del vescomtat de Cabrera el 1387 per a satisfer els deutes contrets a causa de la compra, per part del vescomte, dels castells de Blanes i de Pallafols; cf. J.M ${ }^{\text {a }}$ PONS Guri, Llibre de la universitat de la vila de Blanes, p. 125. Aquest deute, segons es declarava més tard, muntava a prop de $22.000 \mathrm{ll}$.

${ }^{32}$ Com es deia a Santa $\mathrm{M}^{\mathrm{a}}$ del Pla el 1401: "per tal com mestrant experhiència sabem que altres lochs qui per multiplicació de deutes eren en cars de destrucció, per ordinació de dotzè e altres semblants an presa o prenen reparació..."; AHAT, Registra Negotiorum, 1401, fols. 77 r. -78 r.

${ }^{33}$ Algunes poblacions l'obtingueren per 12 anys: com el dotzè atorgat a Santa $\mathrm{M}^{\mathrm{a}}$ del Pla el 1380 (vigent fins el 1392, doncs) o el redelme concedit a la parròquia de Badalona el 1388 per igual període; ACA, C, reg. 1893, fols. 91 v. -92 v.
} 
d'aquest tipus ${ }^{34}$. De moment, tenim referències de més d'una cinquantena de llocs, sense tenir en compte molts nuclis secundaris que s'inclouen dins d'altres ${ }^{35}$.

Pel que concerneix, doncs, a la seva distribució geogràfica, podem assenyalar diferents zones on aquest impost, segons sembla, va tenir una major difusió: d'una banda, la zona pirenaica, sobretot la part central a un i altre costat de la serralada; i, d'una altra banda, les comarques de l'Urgell i el Camp de Tarragona, a part de localitats disperses, situades tant a l'interior com a la franja marítima.

Prenent en consideració els anys corresponents a la primera referència documental que tenim a l'aparició de l'impost en els diferents llocs classificats, podríem dir que l'impost es va generalitzar durant la segona meitat d'aquell segle - de forma més intensa en el darrer terç- fins a principis del segle $\mathrm{XV}$, a partir de quan registrem un menor nombre de concessions (vegeu llistats annexes). Per altra banda, potser no és fortuït que les primeres concessions ja citades estiguin localitzades en regions ultrapirenaiques com el Roselló i el Conflent, així com en zones pròpiament pirenaiques - com la Cerdanya-o subpirenaiques - com la vall de Ribes-. Potser fou per influència occitana que l'ús d'aquest impost es va difondre a Catalunya de nord a $\operatorname{sud}^{36}$. Ens consta que unes ciutats varen seguir

\footnotetext{
${ }^{34}$ Elaborat a partir de les informacions recollides i anotades en els llistats de l'Apèndix. Aquest mapa és provisional, ja que a mesura que disposem de més dades, es podrà ampliar tant el nombre de localitats com les referències concernents a una mateixa localitat.

${ }^{35} \mathrm{Hi}$ ha algunes jurisdiccions, com la baronia de Cabrera, el comtat d'Urgell (amb el vescomtat d'Àger), el marquesat de Camarasa i la baronia de Bellpuig d'Anglesola que agrupaven diverses poblacions, encara que en el mapa corresponent sols assenyalem les principals. Pel que concerneix al vescomtat de Cabrera, es refereix tan sols a una part del mateix, és a dir, les poblacions més pròximes a la costa: Arbúcies, Blanes, Hostalric (la principal de totes), Maçanet, Riudarenes, Sant Esteve de Tordera i Vidreres, a més dels castres de Montclús i de Montpalau; cf. J.M ${ }^{\mathrm{a}}$ PONS GURI, Llibre de la universitat de la vila de Blanes, p. 124. Pel que respecte al comtat d'Urgell (juntament amb la baronia d'Àger), la llista és extensa. Balaguer i Agramunt són les poblacions de major entitat, però n'hi ha moltes altres: Àger, Albesa, Anya, Boix, Ivars, Linyola, Menàrguens, Montmagastre, Montargull, Oliana, Ós de Balaguer, Ponts, Puigverd, Tartareu, Tiurana i Vilaplana, segons la informació continguda a la concessió de 1373 , però sense ser tampoc exhaustius. El marquesat de Camarasa incloïa, a més de la titular, altres poblacions com Cubells, Llimiana, Montgai, Vilanova de Meià, etc. Per al cas de Bellpuig (baronia pertanyent a la família dels Cardona), la concòrdia de 1457 incumbia, a més de la titular, altres poblacions com Sant Martí de Maldà, Vilanova de Bellpuig, Golmes i Castellnou de Seana. Per últim, la vall de Ribes incloïa diverses parròquies: Queralbs, Pardines, Ribes de Fresser, Planoles, Campelles, Ventolà, Bruguera i Fustanyà.

${ }^{36}$ Es tracta, a més, d'un fenomen no exclusiu del Principat. Coneixem, si més no, l'establiment d'impostos d'aquest tipus en alguns llocs de la Provença, com Martigues, pel cas d'un vintè imposat el 1383; cf. Y. GRAVA, Fiscalité, organisation de la société et répartitions
} 
l'exemple d'altres, segons apareix indicat a la concessió donada a Cervera el 1381, quan l'infant Joan aprovà uns capítols com els que ja havien estat concedits als lleidatans.

De tota manera, si ens atenim als resultats del mapa en qüestió, romanen moltes zones del Principat en blanc. En algunes comarques l'impost no va tenir a penes difusió o bé aparegué més tard (ja en època moderna) $\mathrm{i}$ sols en algunes localitats, tot i que, hem d'insistir, un cop més, en el caràcter provisional de la recerca. De moment, tenim documentades algunes ciutats que amb major o menor periodicitat utilitzaren aquest instrument fiscal $\left(\right.$ Cervera $^{37}$, Puigcerdà ${ }^{38}$, Vilafranca ${ }^{39}$, Figueres ${ }^{40}$, Manresa ${ }^{41}$, etc. i, segons l'indicat abans, també Lleida), mentre que n'hi ha altres (com Montblanc) que van tenir intenció d'imposar-lo algun cop ${ }^{42}$. En canvi, sembla que en altres ciutats, com Barcelona, Girona, Tarragona..., ni tan sols es plantejà la possibilitat d'establir-lo, almenys mentre no es demostri el contrari. En certa manera podria dibuixar-se una divisòria entre les ciutats de l'interior, com Cervera i altres poblacions, on l'economia de tipus agrari, o bé la producció basada en la comercialització de determinats productes

des pouvoirs en Provence: Martigues au XIV siècle, dins Études sur la fiscalité au Moyen Ages. Actes du 102 Congrès National des Sociétés Savantes. Limoges, 1977, t. I, París, 1979, pp. 151169 (p. 162 pel que fa a la cita), o com a Grasse, on es té constància d'un delme establert el 1450 per tal de pagar els deutes del municipi; cf. G. GALTHIER-ZIEGLER. Histoire de Grasse au Moyen Age (1155-1482), París, 1435, p. 178. Són dos exemples només d'una pràctica fiscal que deuria ser coneguda en altres regions i viles del Midi.

${ }^{37}$ Les concessions donades a Cervera són de 1381 (per cinc anys), 1414 (tres anys) i 1439 (deu anys), encara que es tenen notícies de la seva percepció abans ja del primer any indicat; vegeu, en aquest aspecte, M. TURULL, La configuració jurídica cit., pp. 523-25. Agraïm de nou la cortesia de Pere Verdés per la informació proporcionada sobre aquesta localitat.

${ }^{38}$ Tenim notícia de dues concessions reials (1345 i 1361), segons el que ja hem comentat anteriorment.

${ }^{39}$ Segons el Llibre Verd de Privilegis el 1379 el rei concedí un privilegi a la universitat de poder imposar perpetualment setzens $\mathrm{i}$ de poder fer ordinacions sobre això. No obstant aquest pretés caràcter perpetual, ens consta que en temps de Joan I, concretament el 1394, s'autoritzà a la mateixa universitat de collir un redelme per tal de redimir censals i pagar els deutes; ACA, C, reg. 1909 , fol. $34 \mathrm{v}$.

${ }^{40}$ Tenim constància de dues concessions: una del 1387 i una altra del 1392.

${ }^{41}$ El 1416 el Consell d'aquesta vila decidí imposar (potser per primera vegada atesa la forma a com s'hi fa referència) un "dret appellat onzè"; AHCM, Manual del Consell, 1416-22, s.f. Esperem que l'historiador i arxiver Marc Torras publiqui alguna cosa amb informació més detallada sobre aquest onzè.

${ }^{42} \mathrm{El} 1387$ en aquesta capital de vegueria es plantejava com a possible via l'arrendament d'un deè, quart o quint, o altra part d'esplets, entre altras mesures destinades a redimir censals; de tota manera, la resposta del rei eludia qualsevol pronunciament de caire afirmatiu; ACA, C, reg. 1890 , fols. $70 \mathrm{i}$ ss. 
agraris, devia de ser molt important en relació amb altres activitats, i les ciutats marítimes (com Barcelona i Tarragona), on el volum o el tipus d'activitat econòmica i mercantil permetria obtenir majors ingressos de les imposicions o d'ajudes d'altra mena, cosa que feia innecessari el recurs a impostos com els que ara centren aquest estudi.

\section{NATURALESA DE L'IMPOST}

Abans de passar a descriure les característiques de l'impost i d'intentar desbrossar la tècnica impositiva, caldria deixar clar la seva naturalesa, és a dir, si es tracta d'un impost directe o indirecte ${ }^{43}$.

D'antuvi, sembla que es tracta d'un impost directe pel fet que gravava béns mobles, encara que només els considerats com a guanys. De fet, es contraposa a les talles, amb les quals no s'ha de confondre, ja que aquestes gravaven sobretot els béns immobles (cases, terres, etc.). En el cas que ens ocupa no es tracta, doncs, d'un impost directe sobre béns patrimonials, sinó sobre la producció agrària (collites) i ramadera, i també sobre els rendiments del treball (salaris), l'obtenció de rendes i de guanys de qualsevol mena. Per això, potser la millor forma de referir-se a aquest tipus de punció fiscal sigui com a impost sobre la renda. Certament, podríem considerar altres enunciats (impost sobre la producció i/o sobre els guanys; impost sobre part de les collites..) que resulten insatisfactoris, ja que no abarquen tot l'àmbit d'aplicació. En darrera instància, podríem tenir en compte el nom més genèric que utilitzaven els coetanis, o sia, el de "redelme", amb la qual cosa es contraposava el delme senyorial al municipal, altrament dit segon delme. En tant que impost sobre la producció agrària (impost que podríem qualificar també de predial), es reproduien els mecanismes del delme i altres rendes senyorials que gravaven les collites. Però l'àmbit impositiu és molt més ampli que això, ja que gravava, de fet, tot tipus de guany, inclosos salaris percebuts per qualsevol feina realitzada, segons anirem veient de forma detallada més endavant. Es tractava d'un impost sobre els rendiments

\footnotetext{
${ }^{43}$ Com se sap, per impost directe hem d'entendre tota exacció que grava els actes de producció o que té com a matèria imposable els béns (tant mobles com inmobles) i les rendes percebudes per les persones. En canvi, un impost indirecte grava activitats, o sia, les transaccions comercials, o bé la circulació de béns, o encara la prestació de serveis de diversa índole $\mathrm{i}$, en general, els actes de consum.
} 
del treball tant agrícola com artesanal, al marge de la possessió de béns i de les transaccions realitzades amb aquests béns. En suma, gravava tot allò que generava un benefici o guany, ja s'anomeni collites, rendes, salaris o simplement guanys, de manera que el títol escollit (impost sobre la renda) és segurament el que millor s'escau pel fet d'englobar tot l'univers conceptual de l'impost en qüestió.

De tota manera, aquest impost no sembla representar cap novetat substancial si és que es limitava a reproduir els mecanismes de la renda senyorial, és a dir, si sols gravava les collites i els productes agropecuaris. Per contra, quan el seu àmbit d'aplicació va més enllà del que ja era gravat per mitjà dels delmes (que percebia la senyoria), és a dir, quan també s'imposava sobre els salaris i guanys, és aleshores quan podem parlar d'un impost veritablement novedós, que en bona mesura pot prefigurar el modern impost sobre la renda. En aquest sentit, l'impost presenta certa ambivalència: depenent de la seva forma concreta d'aplicació - cosa que ja podem observar a partir del ventall de productes que eren objecte de gravamen a cada lloces podrà concebre com un impost, si es vol, avançat per l'època, o ben al contrari, quan l'únic que feia era sobreposar-se al sistema feudal d'exacció. En suma, la valoració de l'impost (com qualsevol altra modalitat impositiva) s'ha de fer depenent sempre de les activitats específicament gravades a cada localitat i a cada època, segons el que anirem indicant més endavant.

\section{SUBJECTES FISCALS I ÀMBIT D’APLICACIÓ}

En tant que impost directe, els subjectes eren els mateixos que ja contribuien a les talles, tal com apareix indicat més d'un cop en els capítols on s'estableix la forma de percepción ${ }^{44}$. Eren, doncs, tots els habitants del lloc (vila i terme), els quals havien de contribuir pels guanys obtinguts tant dins com fora del terme. No obstant això, i a fi d'evitar duplicacions, la contribució fora del terme quedava invalidada quan ja es contribuïa en

\footnotetext{
${ }^{44}$ Alguns exemples són fefaents en aquest sentit: "És entés, emperò, tots aquells qui paguen ni contribuexen en questes e en talles en la universitat del dit loch" (Santa M $^{\mathbf{a}}$ del Pla/1380); "qui són acustumats de pagar en talles comunes" (Tamarit/1380).
} 
aquells llocs veïnals per drets similars ${ }^{45}$. Per altra banda, havien de contribuir també els foranis que obtinguessin algun tipus de guany, com ara per les collites procedents de les terres que posseïen dins el terme munici$\mathrm{pa}^{46}$. Per consegüent, i com qualsevol altre impost percebut pel municipi, el criteri pel qual quedava fixat l'àmbit d'aplicació territorial era la mateixa jurisdicció municipal. Ara bé, aquest àmbit territorial podia no ser plenament coincident amb l'àmbit de percepció dels delmes de la senyoria, a part que quedaven excloses de qualsevol exacció les terres dominicals i les que estiguessin en possessió d'altres persones considerades exemptes ${ }^{47}$.

Tocant, doncs, a la vessant personal de l'impost, els principals exempts eren, com de costum, les persones privilegiades, ja es tractés d'eclesiàstics o de nobles, i certs col-lectius (com els jueus), segurament els mateixos que ja eren eximits del pagament del delme senyorial. Per exemple, a Constantí (capítols de 1381) gaudien d'exempció l'arquebisbe i el paborde, com és lògic, però també el rector i qualsevol altra persona que fos ordenada en ordes sagrades. A Agramunt (1391), com a exempts figuren els preveres, els ordes militars $\mathrm{i}$ els jueus. Altres vegades es fa referència a exempcions

\footnotetext{
${ }^{45}$ Apareix indicat, per exemple, a Valls (1394), quan es mencionen els cereals i llegums que es collien fora del terme: "Però és entés que, si en lo loch on se conrarà paga onzè, que no sia tengut assí de pagar onzè"; i també a Piera (1377) es donava igual reserva per al cas de les rendes: "...si, donchs, en aquell loch on les dites rendes hauran no paguen ja reedelma".

${ }^{46}$ Tots els capítols s'expressen amb termes similars, encara que no sempre amb la mateixa claretat: "tot hom qui poblat sia dins la vila o terme d'Apiera, axí matex fora lo dit terme, qui laurons haja dins la vila o terme dessúsdit, que pach e haja a pagar readelma d'açò que en sos laurons levarà o cullirà, etc."; ACA, C, reg. 930, fols. 160 r.-161 r. A Mont-roig del Camp (1406) havien de contribuir tots els habitants i terratinents "quas colant, laborent vel colligant, per se vel alios, tam in termino dicti loci quam extra ipsum terminum"; AHAT, RN (1406-07), c. 6 , n. ${ }^{\circ} 15 \mathrm{a}$, fol. $30 \mathrm{r}$.-v. Malgrat tot, per al cas de Riudoms (1386) s'exceptuaven les terres pertanyents als veïns de Reus, així com altres terres que, a pesar de formar part encara de la parròquia, estaven ubicades en l'anomenat Territori de Tarragona, fora, doncs, de la jurisdicció municipal. Pel que concerneix a les terres dels veïns de Reus, sabem, segons les nostres informacions, que aquests ja contribuien en els onzens imposats a la seva vila. En canvi, a Vilaverd (1404) els terratinents no pagarien el "deè" per les seves terres, però seguirien contribuïnt en les qüèsties anuals fins que el dit lloc fos deslliurat dels seus deutes, la qual cosa es justificava "per tant com aquells no han cessionat llurs béns axí com han los habitants del dit loch, ne són en lo compte e càrrechs que són tinguts etc."; si es domiciliaven en aquell lloc, pagarien el dit delme a l'hora que estarien exempts de pagar la qüèstia; cf. F. CoRTIELLA, Historia de Vilaverd, p. 192.

${ }^{47} \mathrm{~A}$ les poblacions pertanyents a la baronia de Bellpuig (1457) s'exceptuaven les terres del senyor i totes aquelles altres pertanyents als cavallers i als clergues: "És entés, emperò, que si les dites terres se conrearan per persones o en nom de persones no privilegiades, paguen e sien tenguts pagar lo dit onzè, com solament ne escepten si seran conreades per lo senyor, cavallés, gentil hòmens, e frares e capellans en les terres de la sglésia pròpies"; cf. R. MiRó, art. cit., p. 21.
} 
puntuals: a Cervera (1381), tocant al dret percebut sobre el vi, s'eximia els estudiants, a més dels clergues i els jueus.

Els administradors i subordinats dels senyors es beneficiaven d'exempcions, així, per exemple, per les activitats realitzades a les corts dels batlles. En el cas de Constantí s'indica que els escrivans dels senyors no havien de contribuir, potser per la seva condició de clergues, segons el que s'hi fa constar, però a continuació es menciona també l'escrivà de la cort com a exempt de totes les escriptures realitzades al servei de la cort, entenent per això els guanys obtinguts pel seu treball. També a Reus (1388) es consideraven exempts - per igual motiu - els escrivans dels dos senyors de la vila (cambrer/castlà); i tant a Constantí com a Reus quedaven eximits els recaptadors de les rendes senyorials, o sia, per les mateixes rendes.

Una de les preocupacions dels dirigents municipals era evitar que els $\mathrm{col} \cdot$ lectius de privilegiats prenguessin possessió de béns contributius, en tant que era una forma de defraudar al municipi. Per exemple, a Piera (1377) es prohibia el traspàs de béns a mans de persones privilegiades, on s'advertia, a més, que durant el temps que durés la percepció del "redelme", ningú no podia realitzar cap traspàs a favor de persones privilegiades (clergues 0 cavallers) sobre cap tipus de rendes, o sia, "de censals, violaris, censes o altres qualsevol rendes". Semblants disposicions es donen pel cas de les talles.

Per altra banda, estaven exemptes totes aquelles persones que haguessin obtingut del municipi alguna franquesa tempora ${ }^{48}$. Efectivament, com tenim comprovat en el cas de Reus, l'onzè figura, entre d'altres contribucions, en les franqueses atorgades pel municipi a partir de finals del segle XIV, justament d'ençà que l'impost es començà a recaptar en aquesta vila $^{49}$. No tots els municipis van mostrar sempre la mateixa disposició per atorgar franqueses d'onzens, com podem veure pel cas de la baronia de Bellpuig $(1457)^{50}$. A banda, no a tot arreu es respectà la condició d'aquests

\footnotetext{
${ }^{48}$ "En les coses damunt dites no sia entés de pagar negú que aja franquesa" (Reus/1388); "Són-ne acceptats [= exceptuats] tots aquels qui franquea puxen alegrar" (Valls/1394); "...que los dits jurats e prohòmens no entenen que en los damunt dits capítols sia entesa neguna persona privilegiada ni franqua puxa adlegar, ni d'aquella stima alegrar, ab aquest present capítol lo'n foragiten (...); e açò és entés de totes persones que ha al dia d'uy" (Alcover/1393).

${ }^{49}$ Sobre aquesta qüestió, J. Morelló, Fiscalitat i finances cit., cap. 6.2., p. 632 i ss.

${ }^{50}$ Efectivament, en la concòrdia establerta amb els creditors s'inclou un capítol (el 14è) prohibint d'atorgar cap franquesa ni fer franc d'onzè a cap nouvingut durant el temps en què l'impost estigués vigent; cf. R. MIRÓ, art. cit., p. 26. Altrament, aniria en perjudici de la
} 
enfranquits: a Agramunt (1391) haurien de contribuir per mor de certs productes (cereals, verema, safrà i altres fruits), encara que únicament els conreats dins del terme $\mathrm{i}$ exclosos els procedents de fora ${ }^{51}$. En tant que parlem, però, d'exempcions temporals, aquests nous residents esdevenien contribuents (d'onzens i altres impostos municipals) quan el període de temps convingut arribava a la fi.

\section{TAXES APLICADES}

Com ja hem pogut veure, la taxa aplicada donava nom a l'impost. L'elecció d'una taxa (i, per tant, el grau de sostracció) era una opció del municipi des del moment que els dirigents locals prenien la decisió pertinent. Així trobem que a Mataró (1391) el rei donà permís per poder imposar un onzè o altra proporció (es menciona un octavum, sextum, quint o encara un redelme), la qual cosa indica clarament, segons el que també observem en altres localitats, que l'elecció de la taxa havia de ser quelcom decidit pels dirigents municipals segons les seves necessitats. En altres casos s'optava per percebre l'impost de la mateixa manera a com es cobraven els delmes senyorials $^{52}$.

Segons les dades disponibles fins al moment, les taxes que podem considerar més freqüents estan compreses entre un 5 i un $10 \%$ i són les següents: deè, equivalent al 10\% (o també "redelme", encara que no sempre poden ser considerats com a termes sinònims); onzè $(9,09 \%)$; dotzè $(8,3 \%)$; i vintè $(5 \%)$. En algunes viles (Cervera, Vilafranca) s'aplicaren també setzens $(6,25 \%)^{53}$.

col.lecta, cosa que no interessava als dits creditors, en tant que es feien responsables de la recaptació.

51 "e no d'aquells que culliran en les terres llurs pròpies que han en los lochs d'on se són mudats o.s mudaran a la dita vila, com açò sie més profit dels dits arrendadors que dapnatge".

${ }^{52}$ A Piera (1377), on els delmes del bestiar i dels productes derivats es pagaven al convent de Pedralbes, es feia contribuir a compte del redelme "segons que al dit monestir són acostumats de donar".

${ }^{53}$ Altres taxes menys corrents serien un quinzè $(6,6 \%)$, com l'imposat a Cubelles el 1407 ; $\mathrm{o}$ inclús taxes més gravoses que el propi delme, com el novè $(11,1 \%)$ i vuitè $(12,5 \%)$ imposats a Anglesola segons informa A. BACH, Història d'Anglesola, Anglesola, 1987, p. 67. A part dels termes indicadors d'alguna taxa, caldrà tenir en compte un altre terme de distinta significació, como el de "milanar", que fou adoptat en algunes poblacions del Camp de Tarragona ja al segle $\mathrm{XV}$, encara que referit a una particular forma d'imposició, segons veurem més endavant. 
Normalment, s'optava per una mateixa taxa per a tots els productes i activitats que es pensaven gravar. No obstant això, algunes vegades les taxes podien ser diferencials segons el producte considerat: així ho ha comprovat Pere Verdés en el cas de Cervera en diferents moments. El 1381 es pensava gravar les collites amb la proporció $1 / 16(6,25 \%)$, mentre que, pel que es refereix a les rendes, la taxa (expressada per lliura) era variable: un $7,5 \%$ quan es tractava de censals, un $5 \%$ pels violaris i un $10 \%$ pels censos; en altres tipus de guanys era del 7,5\% i, en el cas dels salaris, del $5 \%$. El 1414, la taxa escollida fou la d'un dotzè $(8,3 \%)$, tant per a les collites com per a les rendes, mentre que en el cas dels guanys es mantenia igual que el 1381, és a dir, amb diferents taxes a pesar de la denominació general. El 1439 els cereals serien gravats de nou mitjançant un setzè $(6,25 \%)$, mentre que les rendes ho havien de ser amb un delme $(10 \%)$. Un altre exemple de taxes diferencials es presenta al Camp de Tarragona, en concret, a Santa Maria del Pla (1380). En efecte, en aquesta localitat es mencionen tres taxes diferents (un deè, un onzè i un dotzè), a banda d'altres gravàmens particulars, segons l'indicat a la taula adjunta:

\begin{tabular}{||l|l||}
\hline \multicolumn{1}{|c|}{ Productes } & Taxes \\
\hline cereals/llegums & $1 / 12(8,3 \%)$ \\
\hline verema & $\begin{array}{l}1 / 10(10 \%) \text { indicat: "la deena soma- } \\
\text { da" }\end{array}$ \\
\hline olives & $1 / 11(9,09 \%)$ \\
\hline lli/cànem & $1 / 12(8,3 \%)$ \\
\hline safrà & $1 / 10(10 \%)$ \\
\hline verdures/ hortalisses & $1 / 10(10 \%)$ \\
\hline llanes & $1 / 10(10 \%)$ \\
\hline formatges & $\begin{array}{l}\text { segons el que es paga a l'arquebisbe } \\
\text { i al paborde }\end{array}$ \\
\hline anyells/cabrits & $\begin{array}{l}3 \mathrm{~d} \text {. per anyell/cabrit (o bé cobrat en } \\
\text { espècie })\end{array}$ \\
\hline porcells & $2 \mathrm{~d}$. per porcell \\
\hline
\end{tabular}




\begin{tabular}{||l|l||}
\hline $\begin{array}{l}\text { avirall (polls, ànecs, } \\
\text { oques) }\end{array}$ & $\begin{array}{l}\text { tant com pertany als delmers dels } \\
\text { senyors }\end{array}$ \\
\hline farratge & $1 / 10(10 \%)$ \\
\hline
\end{tabular}

Cal suposar que aquestes taxes serien les mateixes que percibia la senyoria en aquell lloc (concernent, en aquest assumpte, tant a l'arquebisbe com al paborde de la Seu de Tarragona ${ }^{54}$ ), tenint en compte, a més, que els delmes senyorials no sempre es corresponien a la desena part, com es demostra en alguns dels estudis realitzats sobre aquesta renda $a^{55}$.

També podien ser diferents les taxes en base a d'altres supòsits: com exemple podem mencionar el dotzè establert a Alcover el 1393, on el gravamen sobre les collites obtingudes fora del terme es reduïa a la meitat de la taxa stàndard, o sigui, a $1 / 24(4,16 \%)^{56}$. Tocant a l'onzè imposat a Tàrrega (1377), els cultivadors que no fessin domicili a la vila, però que tinguessin a càrrec seu terres pertanyents als habitants de la vila, ho farien sols en un $1 / 20(5 \%)$, encara que només es cobraria si existia el costum de contribuir-hi ${ }^{57}$. Però, en general, no es donaven taxes diferencials, sinó una de sola per a tots els supòsits o per a tots els productes que estaven subjectes a contribució.

L'impost era percebut després que els collidors de les rendes senyorials (delmes i primícies) haguessin cobrat la part que els corresponia $^{58}$. Sols en un cas (Alforja/1393) tenim constància d'un dotzè que es

\footnotetext{
${ }^{54}$ Com se sap, els perceptors dels delmes no sempre s'identifiquen amb els titulars de la jurisdicció. A Piera, que era lloc reial, s'imposà un redelme (1377) a percebre -en alguns aspectes- "segons que són tenguts de pagar al monestir de Sancta Maria de Pedralbes". Per al cas de Riudoms (1386) es feia contribuir per les collites obtingudes d'altres terres i masies que no pagaven delme a l'arquebisbe ni al paborde de la Seu sinó al rector de la localitat.

${ }^{55}$ Per al regne de Mallorca, vegeu els treballs de J.F. LÓPEZ com, per exemple, el titulat: $L$ 'estudi del delme recaudat per la procuració reial de Mallorca en el segle XIV $i$ el seu interès respecte a l'aproximació a la conjuntura agrària, "Bolletí de la Societat Arqueològica Luliana", 39. (1983), pp. 381-406.

${ }^{56}$ Apareix indicat com a mig dotzè: "entés de XXIIII(tre) mesures una".

${ }^{57} \mathrm{Cf}$. Ll. SARRET, Privilegis de Tàrrega, p. 304.

${ }^{58}$ Això significa que l'aplicació, per exemple, d'un onzè $(9,09 \%)$ seria, en realitat, equivalent a un $8,18 \%(1 / 11 \times 9 / 10)$ en relació al global de la collita; un dotzè $(8,3 \%)$ seria poc més d'un $8 \%$, i així successivament, ja que es prenia -teòricament- de $9 / 10$ parts.

Tenint en compte els punts afins que es donen entre l'estudi dels delmes senyorials i municipals, entenem que és d'interès comú conèixer el funcionament d'uns i altres; però, de moment, és molt poc el que se sap a Catalunya sobre el delme senyorial dels segles medievals
} 
faria pagar directament del global de la collita i no després d'haver satisfet els corresponents drets senyorials ${ }^{59}$. D'acord amb la taxa enunciada, l'impost es percebria sobre el global de la collita o bé tenint en compte les mesures pròpies de cada producte (naturalment, sempre que fos satisfet en espècie). Així, a Tàrrega (1377) s'indica que d'11 mitgeres (per a tot tipus de cereals) se'n pagaria una; de cada 11 somades (de verema), una; i, de cada 11 lliures de bri de safrà, una ${ }^{60}$. També es podia donar l'opció de realitzar el pagament en l'equivalent en diner; aleshores, el gravamen podia ser expressat segons una taxa també proporcional, la qual cosa confereix una gran similitud amb el sistema de taxació de les talles ${ }^{61}$. De fet, en alguns llocs s'adoptaren formes de taxació pròpies de les talles (amb taxes expressades per "milanar", tal com trobem indicat en vàries poblacions del Camp de Tarragona d'ençà el primer decenni del segle XV), tot i mantenirse com un impost (a partir d'aleshores anomenat, curiosament, milanar) que també requeia sobre les collites i que podia ser cobrat tant en espècie com en diner, segons el que veurem més endavant.

\footnotetext{
pel que fa almenys a la qüestió que aquí més ens interessa, que és la forma de percepció. Per a Catalunya, no coneixem, per a època medieval, cap estudi global sobre el delme que analitzi la forma de percebre'l més enllà d'algun estudi centrat en una localitat o comarca de forma exclusiva. Vegeu, en especial, els treballs de Fl. SABATÉ, Fiscalitat i feudalisme. Tàrrega, 1329: recompte $i$ reestructuració, Barcelona, 1991, pp. 37-39; i A. VIRGILI, El delme i la primícia al bisbat de Tortosa "Analecta Sacra Tarraconensia", 67/1 (1994), pp. 423-431 (abans fou publicat a "I Congrés d'Història de l'Església Catalana" (Solsona, 1993), pp. 423-31). Per a època moderna, el tema ha merescut una major atenció: vegeu, per exemple, G. FELIU, $E l$ funcionament del règim senyorial cit., p. 36 i ss. respecte de la comarca de l'Urgell.

59" que lo dotzè se haja a pagar comptant de la primera mesura tro a la dotzena, no detrahent-ne alcun altre dret o càrrech de delma ni de promeya, ni tascha ni negun altre dret, axí que verdaderament sia donat lo dotzè bé"; no obstant, s'advertia que aixồ no havia de comportar una disminució dels delmes i altres drets de la senyoria; ACA, C, Procesos, 114/7, fol. 13 r. i ss. Aquest procediment, que comptava amb el consentiment de l'arquebisbe, s'explica potser perquè aquella taxa s'imposà per a pagar les quantitats degudes per l'arquebisbe i les mateixes universitats en la compra a la monarquia de les jurisdiccions del Camp el 1391, segons ja havíem dit.

${ }^{60} \mathrm{Cf}$. Ll. SARret, Privilegis de Tàrrega, p. 299.

${ }^{61}$ En els capítols cerverins de 1381 , per exemple, s'estableixen diferents taxes proporcionals ( 2 sous per lliura, 18 diners per Iliura, etc.), mentre que les fraccions són reservades per als pagaments en espècie. Simplement, es tracta de distintes formes d'expressió que es poden reduir a un mateix percentatge: així, per exemple, un vintè (1/20) és el mateix que una alíquota d'1 sou per lliura, és a dir, un $5 \%$ en ambdós casos.
} 


\section{MATÈRIA IMPOSABLE}

L'amplitud de productes que eren gravats amb aquest impost es recolzava en la universalitat que es donava al delme, com a forma de sostracció establerta sobre tot tipus de fruit. Aquests fruits eren, en primer lloc, els obtinguts al camp, tant agrícoles com també ramaders. Com se sol indicar, eren tots aquells que ja contribuïen en el pagament dels delmes senyorials $^{62}$, fins al punt de què, en el cas d'existir algun producte que no contribuís al delme, cosa que era bastant infreqüent, tampoc hauria de contribuir a compte de l'onzè, tal com es declarava a Agramunt en cert $\operatorname{cas}^{63}$.

Depenent del lloc i del moment, l'impost podia cobrir una gamma molt variada de productes o afectar només uns quants, segons queda reflectit a les taules de l'Annex on anotem diversos exemples locals. L'impost s'adaptava a l'estructura productiva de cada lloc, de manera que l'elecció d'uns o altres productes no era gens banal si del que es tractava era, naturalment, de fer rendible l'impost. En especial es tendí a gravar aquells productes que en termes de producció devien destacar: no sols els més bàsics (cereals, verema...) sinó també els més específics de cada comarca, com el safrà - a la Segarra i a l'Urgell- o l'oli —al Camp de Tarragona- .

En les línees que segueixen, anirem indicant quins productes en concret eren gravats i de quina manera, o sia, en quin moment $i$ en quin lloc o llocs es percebia l'impost. Són qüestions que podem conèixer gràcies sobretot als capítols (la majoria d'ells inèdits) corresponents a diferents localitats (vegeu llistat adjunt). Prenem en consideració quatre grups: a) Productes agrícoles; b) Productes ramaders; c) Rendes; d) Guanys i salaris.

\section{a) Productes agrícoles}

-Cereals (collites en general)

\footnotetext{
${ }^{62}$ Com a Riudoms (1386): "I reradelma de blat e de legums, e de venema, e d'olives, e de totes menudaries semblantment que'l senyor archabisbe e lo senyor pabordre prenen en lo terme de Riudoms". A Piera (1377), a propòsit també d'un redelme, aquest es pagaria, almenys en certs casos, "segons que al monestir [de Pedralbes] és acustumat". No es descarta, doncs, que la utilització del terme "redelme" obeeixi a aquest mimetisme envers la renda senyorial.

${ }^{63}$ Referit sols al farratge, per la qual cosa donem la cita més endavant, en l'epígraf corresponent.
} 
La taxa requeia sobre tot tipus de cereals (blats grossos e menuts). Els més corrents serien el forment, l'ordi, la civada i també el sègol, entre d'altres cereals indicats en alguns capítols ${ }^{64}$.

Com ja sabem, l'impost es cobrava en espècie després del delme $\mathrm{i}$ la primícia, considerats drets preferents en tots els casos. El lloc del cobrament era a les eres ${ }^{65}$, d'on no es permetia treure la collita abans que el recaptador fes acta de presència ${ }^{66}$. En canvi, per a les collites obtingudes fora del terme, es donava un termini de varis dies per a pagar-lo des del moment que s'hagués fet la batuda ${ }^{67}$. També es feia pagar per les parts de collites, independentment de la fórmula emprada (" $a$ blat $o$ a dinés $o$ a qualsevull altre loguer", com es deia a Valls el 1394). Això incumbia tant aquells que conreaven terres fora del terme com aquells altres que les donaven a cultivar a un altri ${ }^{68}$.

Quant a la forma més concreta de percepció, hi havia una manera preferent de percebre'l a l'era: en garba. A Piera (1377) el "redelme dels blats" havia de donar-se en garba i així mateix a Agramunt (1391), on, a propòsit d'això, es declarava: "daran lo XIè dels blats damunt specificats en garba, si als dits arrendators lo.i volran". A Reus (1388) això era aparentment opcional, ja que es podia detraure en garba si així ho preferia el recaptador. En els pobles de la baronia de Bellpuig (1457) es donava igual poder de decisió als recaptadors ${ }^{69}$. En canvi, el Consell cerverí decidia (el

\footnotetext{
${ }^{64}$ En alguns capítols s'indiquen distintes espècies: "...de tots blats: ço és, de forment, d'ordi, d'avena e de tots altres blats menuts qui.s culliran etc." (Cervera/1381); "axí com de forment, mestall, ordi, avena, paniç, mill, e de tots blats etc." (Santa $\mathrm{M}^{\mathrm{a}}$ del Pla/1380); "de tots blats, ço és, forments, ordis, civades, avenes, speltes e mestays, mills, panissos e dacses, e de tots altres blats" (Agramunt/1391); "axí de forment, ordi, avena, segual, mestall com spelta" (baronia de Bellpuig/1457); etc.

${ }^{65}$ Exceptuats els cereals i llegums que es batien a casa, per als quals es donava un temps per a satisfer l'impost: a Reus (1388) i a Valls (1394) s'assenyalen tres dies.

${ }^{66} \mathrm{Per}$ al cas de Cubelles: "que no gosen levar de la era los dits blats tro a tant sien mesurats"; cf. J. CoROLEU, Historia de Villanueva y la Geltrú, p. 122 (de l'edició antiga).

${ }^{67} \mathrm{~A}$ Valls (1394) el termini fixat es feia dependre de la distància que hi hagués en relació al nucli de població: si el cultiu estava ubicat més enllà de 2 llegües s'establia un temps de 15 dies en lloc de 6, que era el temps assignat per a distàncies menors a la indicada.

${ }^{68}$ Naturalment, es faria pagar sols per la part de la qual es beneficiava qui fos habitant de la vila, tal com s'indica a Valls (1394).

${ }^{69}$ "E là hon los dits procurador e collidors del dit onzè volguessen onzenar en guarba, en la era o en lo troç on lo blat serà, que ho puixen fer e variar de un any en-altre segons los plaurà etc." En el mateix capítol es fa referència a diferents termes ("colls", "balegs", "grapissos") per a designar les diferents munteres que es feien en el moment de batre el cereal.
} 
1377) que es pagués amb blat batut, o sigui, en gra $^{70}$. Altres servituds envers els collidors de l'impost concerneixen el transport de la collita. A Vilaverd (1404), el producte de la collita havia de ser portat al graner del recaptador a càrrec, però, del mateix productor.

L'impost també podia ser satisfet en el moment en què la collita era venuda o comprada, independentment del lloc on s'hagués realitzat la transacció, tal com queda indicat a Constantí (1381) i a Reus (1388). A Cervera $(1381 ; 1414)$ la persona que hagués comprat cereals per vendre, hauria de pagar el setzè del preu $(=6,25 \%)$, considerant això com el fruit o pensió que n'obtindria si es convertís a raó de censal mort. El 1414 s'indicava un "for" de conversió del 20 mil per mil (5\%). De fet, tal supòsit (la compra/venda de collites) entraria a formar part més aviat de l'apartat dedicat als guanys mercantils.

\section{- Vi i verema}

L'impost podia ser cobrat a les vinyes. A Constantí (1381), per exemple, s'havia de cobrar en el mateix lloc on es feia la collita, ja fos a la vinya o a l'hort, d'aquí també la distinció entre verema de vinyes i d'horts. Però, en altres casos el lloc de cobrament era a les portes de la vila. A Cervera (1381), on només afectava els habitants de la vila que tinguessin vinyes al terme, es cobraria als portals d'accés a la ciutat. Es feia pagar a raó de $6 \mathrm{~d}$. per somada de mul o rocí i només 4 per somada d'ase (diners barcelonesos), satisfent la prorrata en cas de què la somada no fos íntegra. El 1439 fou rebaixat a 4 i 2 d. per carga de mul i d'ase, respectivament. Així mateix, a la baronia de Bellpuig (1457) es taxava a raó de $3 \mathrm{~d}$. per cada carga de verema, a pagar al portal en el moment d'introduir-la. De fet, el procediment és molt similar (si no, del tot) als anomenats drets d'entrada, un tipus d'imposició amb la qual podria confondre's: en el cas que ens ocupa, els habitants de Cervera ho havien de pagar de la verema que havien collit a les seves vinyes o bé de l'obtinguda de rendes, justificat, doncs, com a producció o com a guany. A part, cada pagès havia de declarar quantes somades de verema havia produït. També a Tàrrega (1377) la verema conduïda a l'interior del recinte de la vila era intervinguda als portals de la vila a fi de poder cobrar després la part corresponent. A Agramunt (1391),

\footnotetext{
${ }^{70} \mathrm{Cf}$. M. TURULl, La configuració cit., p. 525. El 1381, segons els capítols del setzè, es deia simplement que es pagués a l'era.
} 
segons sembla, s'havia d'introduir per certs portals: "e que aquella no gosen metre sens que alcuns dels cullidors del dit XIè no.i sia, a fi que pus leialment se puga donar lo dit onzè". En aquest cas es donava opció als collidors de prendre la part ("somada") que fos de la seva preferència i de portar-la a una casa a càrrec del cultivador. En el cas de no tenir onze somades, s'hauria de pagar 1 sou jaqués per tantes somades que fossin declarades. A Reus (1388), si la verema (produïda dins el terme) s'acabava venent en algun indret fora del terme, llavors l'onzè es percebria a raó de 5 sous per somada.

A més de la verema, també el vi era gravat amb aquest impost. A Cervera (1381) es feia pagar a raó de 5 sous (per somada) cada vegada que s'introduïa a la vila. Es recalca, una vegada més, que no es podia introduir cap altra verema o vi que no fos de les parcel-les pertanyents a la contribució de la ciutat. Tornant a Reus (1388), l'onzè es cobrava tant sobre les vendes de verema com del vi que s'hagués produït dins del terme. Si es tenia intenció de treure'l fora, calia donar-ne avís als jurats o als corredors per tal de ser estimat de manera que es pogués cobrar l'onzena part del preu d'estimació. Els diumenges s'havia de donar compte del vi que s'hagués venut al detall. Per la seva part, els recaptadors cuitarien a segellar les bótes com a mesura de control. Més encara, l'arrendatari podria registrar tot el vi que tinguessin els habitants de la vila i terme.

En altres llocs, en canvi, la percepció de l'impost es feia en el moment de la venda. A Valls (1394) es cobraria en el moment de vendre la verema o el vi ("vullàs lo vena en gros ho en menut") o si la collita es venia abans de la recol-lecció. En cas de què es volgués portar fora del terme, s'havia de manifestar, i es cobraria del valor o preu de l'estimació dictaminada pels jurats. Quant a les persones de fora, es faria pagar sols si el vi -obtingut a les terres ubicades dins el terme o a partir de la compra de verema- era objecte de transacció. Però, cal deixar clar que es feia contribuir pel guany obtingut, i no pas per la transacció en sí mateixa. A Tamarit (1380) s'especifica que, si ja s'havia cobrat sobre la verema, no es podia reclamar cap altra contribució sobre el vi que hagués estat venut posteriorment.

També podem assenyalar que en alguns llocs es feia distinció entre diferents classes de vi en correlació amb tarifes desiguals. Així, a la parròquia de Badalona (1388) es feia pagar $25 \mathrm{~s}$. per cafís de vi, o sigui: 20 $\mathrm{s}$. per cafís de vi pur o most i $5 \mathrm{~s}$. per cafís de reemost, que deuria ser el que quedava del procés d'elaboració. Cada any s'havia de declarar als 
recaptadors tant el vi com el referit most i reemost obtingut pels productors locals.

Amb tot, en el cas de Cervera (1381) i de Valls (1394) s'incloïen altres supòsits pel fet de gravar també el consum de vi (del vi que beuran en lurs cases, com s'indica a Cervera). Per això s'establia una capitació segons l'edat: els majors de 10 anys, pagarien 4 s.; entre $4-10$ anys, 2 s.; mentre que els menors de 4 anys (massa inmadurs per beure vi!) estaven totalment exempts. A Valls, encara que no es fes referència a cap divisió per edats, es tenia en compte el mateix supòsit (del vi que despendrà); per això cada persona estava obligada a declarar el vi que tingués a la bóta abans que comencés a consumir-lo. Aquest fet podria considerar-se una extralimitació, en tant que sembla equiparable a la imposició del vi que també gravava els consumidors i que, per exemple, a Valls s'anomenava justament del beure de casa o el vi dels casolans $^{71}$. Per altra part (sense deixar aquesta vila), consta que l'arrendatari de l'onzè estava facultat per fer una recerca per tota la vila i terme per tal de saber quines eren les existències de cada veí, segons el que hem vist en altres casos. Aquells que volguessin vendre vi al detall havien de donar-ho a conèixer al recaptador, qui s'encarregaria de posar a la bóta el senyal corresponent. Així, doncs, a tot arreu els procediments eren similars.

\section{- Oli}

L'impost tant es podia prendre sobre la producció d'olives com també sobre el producte elaborat, o sia, sobre l'oli. A Manresa (1416) s'indica que s'havia de pagar al trull i en oli. Però és sobretot a les poblacions del Camp de Tarragona on es dóna més rellevància a la forma de percepció, segons mostren els capítols corresponents. A Reus (1388) era satisfet sobre la venda de les olives recollides dins i fora del terme pels habitants de la vila: onzè aplicat, doncs, sobre el preu de venda, tant si es venia en diner com en espècie. Endemés, es donava l'opció de cobrar l'impost en olives o en oli, segons les preferències del recaptador. Els propietaris de les premses (obradors d'oli), que no serien molts, havien de

\footnotetext{
${ }^{71}$ De moment no hem descobert cap diferència entre un i altre tipus impositiu. La inclusió de supòsits com l'indicat, que, sens cap mena de dubtes, suposa una raresa i que s'aparta de l'habitual forma de percepció de l'impost, ens va fer pensar en un caràcter mixte de l'impost (directe/indirecte) quan vàrem publicar els capítols de Valls de 1394, que en certs aspectes són diferents dels altres capítols d'onzens.
} 
contribuir per tot el que guanyessin en aquesta operació. També per la compra o venda d'olives abans de ser recol-lectades es pagaria una onzena part del preu estipulat. Si es venien a persones de fora, el venedor pagaria l'onzè íntegrament, o sigui, de totes les olives. Si es venien a ull ( $a$ barrisch), s'haurien de pesar, si tal era el desig del recaptador. Els foranis pagarien onzè de les olives recol-lectades abans de ser tretes fora del terme o bé abans de transformar-les en oli.

Seguim amb altres localitats del Camp de Tarragona. A Santa Maria del Pla (1380) l'onzè sobre les olives havia de cobrar-se abans de què fossin portades al molí i, per consegüent, abans de què fossin premsades. A Tamarit (1380) s'havia de pagar únicament per les olives, mentre que per l'oli ja no es feia pagar res. A Valls (1394) l'onzè de les olives es feia pagar al molí, però abans també de què passés per la premsa. En aquest cas, a més del delme i la primícia, també s'inclou la moltura com a dret que es descomptava, la qual cosa s'explica perquè el propietari del molí havia de respondre per totes les olives que hagués guanyat del dret de moltura abans que fossin premsades, així com de tot guany obtingut. Com a Valls, també es feia pagar per la venda de les olives abans de la recol·lecció, ja fossin venudes en oli o en diner, de manera que es cobrava del guany obtingut en aquestes transaccions. Per últim, podem citar el cas de Constantí (1381), on es preveia posposar la percepció del deè sobre les olives per no perjudicar la recaptació, tenint en compte que a una collita bona seguia una altra de dolenta.

\section{-Safrà}

Pel que es refereix a aquest producte, hi havia dues maneres de cobrar l'impost: en flor o en bri. A Tàrrega (1377) es feia pagar del bri de safrà quan la planta ja estava seca. El cobrament es realitzaria el novembre tota vegada que estava prohibit de vendre'l abans d'haver satisfet la taxa. A Moià (1378) també es feia pagar del bri; en aquest cas, un vintè. El setzè de Cervera (1381) requeia sobre el safrà en flor. Posteriorment (1414) es faria pagar mitja lliura de safrà sec per cada certa quantitat: "de setze migeres de cabeça de safrà de dos e de tres flors, mitja lliura de safrà sech, bo e rebedor encontinent que lo safrà haurà haüt". En canvi, el safrà considerat "novell" estava exempt de contribució. El 1439 es cobraria a raó de 6 d. per cada mitgera. A Agramunt (1391) podia ser pres de les dues maneres: en bri o en flor, cosa que se sotmetia a la voluntat dels arrendataris. A la baronia de Bellpuig (1457) es faria pagar segons la preferència també dels recapta- 
dors, és a dir, en bri acolorat e sech o bé en flor. A Santa Maria del Pla (1380) s'havia de pagar quan ja estigués sec, segons el costum dels cobradors del delme senyorial. També en altres llocs del Camp de Tarragona s'inclou aquest producte en la contribució dels onzens o similars ${ }^{72}$.

-Hortalisses, verdures, fruites i llegums

En el cas de les hortalisses l'impost s'havia de cobrar als horts o, més en general, on es realitzés la recol-lecció. A cada localitat trobem enumerades diverses espècies vegetals. A Valls (1394) es mencionen alls, cebes, porros, cols, escalunyes i altres plantes (exorovies, scaravies...) prohibint que fossin tretes de la parcel-la abans d'haver pagat la part corresponent a l'impost. A Alcover (1393) es mencionen alls, cebes, escalunyes, pèsols, cols i porros. A Reus (1388) s'inclou una gran varietat de fruites: figues, peres, préssecs, taronges, llimones, prunes, magranes, palma i encara algunes més ${ }^{73}$. A Piera (1377) es pagaria "redelme" de les cebes, alls, cols i porros, a més d'esmentar alguns fruits secs (nous i avellanes). A Badalona (1388) s'indiquen diverses llegums: faves, pèsols, cigrons i llenties; i, com a fruites, es mencionen les figues i les cireres. En el cas de Mataró (1391) s'esmenten els mateixos llegums, a més de pinyons. A Manresa (1416) figura un onzè de tots llegums, exclosos, però, llegums tendres.

\section{-Plantes industrials}

Hem de considerar, en primer lloc, algunes plantes tèxtils (lli, cànem), les quals apareixen enumerades en molts capítols, però sense donar peu, normalment, a consideracions especials. Podem citar el cas exposat a Santa Maria del Pla (1380), on es feia pagar una dotzena part de la garba ("mena") de lli o de cànem a l'hort o al camp on hagués estat cultivat.

\footnotetext{
${ }^{72}$ A Valls (1394) el safrà, a diferència d'altres cultius, no era considerat dins la prohibició general segons la qual els productes collits no podien ser trets de la parcel.la abans que es pagués l'onzè; d'aquesta manera es cobraria el dret un cop s'haguessin portat les fulles a secar al domicili de cada particular. Semblant condicionament apareix indicat a Tàrrega (1377): "per ço com lo safrà és cosa qui.s afora en casa e fora casa donant a liures"; cf. Ll. SARRET, Privilegis de Tàrrega, p. 302.

${ }^{73} \mathrm{Com}$ a variedats s'indiquen "sarmenyes", fruita similar a les peres, però de mida més petita; "poncems", semblant a la llimona (en cast. cidra); "aranges", espècie de taronja gran; "albergens", varietat d'albercoc de primera època, i més petit que l'ordinari.
} 
De tota manera, sota aquest epígraf hem d'incloure plantes que tenien altres utilitats, com el roldor, utilitzat en els processos de curtició de les pells. A Reus (1388), on el cultiu d'aquesta planta sembla haver tingut una especial rellevància, es pagaria després de ser garbellat (cernut $o$ porgat), operació que havia d'estar conclosa el gener. Si es comprava en cultiu (en camp ne en fulla) es pagaria del preu de venda. A Valls (1394) es menciona el roldor com a producte que quedava també exclós de la prohibició relativa a la permanència de les collites al lloc on es feien, puix que, a l'igual que el safrà, havia de passar per un procés d'assecament que necessàriament s'havia de fer al domicili dels productors.

-Farratge

Incumbia, en general, totes aquelles plantes (veces, panis, moresc...) que es donaven com a aliment al bestiar $\mathrm{i}$ als animals domèstics. A Agramunt (1391) es pensava cobrar onzè sobre el farratge que es venia 0 , altrament, sobre el valor estipulat ${ }^{74}$. A Santa Maria del Pla (1380) es faria pagar "redelme" del farratge venut en espècie o en diner ( $a$ blat o a diners). De forma similar, a Constantí (1381) es feia pagar deè del farratge, però sols si es venia, ja fos en diner o en espècie. A Valls (1394) també es mencionen les mateixes plantes indicant que es faria onzenar en el mateix lloc on es recol-lectaven. Endemés, per la venda de palla, llenya, etc., es faria pagar onzè del preu obtingut. En canvi, a Alcover (1393), el farratge, pel que sembla, no estava comprès en el pagament de l'impost ni tampoc altres herbes o plantes com les ja citades.

\section{b) Ramaderia}

\section{-Nadissos}

L'impost requeia sobre la producció, és a dir, sobre les cries i animals joves. A l'igual que les collites, s'havia de satisfer després d'haver pagat els drets corresponents (delmes i primícies). Se solia cobrar en diner (a un tant per cap) o bé en espècie, si així ho preferia el recaptador. Per al cas de Santa Maria del Pla (1380), la forma de pagament la tenim exposada a la taula intercalada abans, on els anyells, cabrits i porcells es relacionen

\footnotetext{
74 "pagaran la honzena part de tot ço que hauran de erbes e ferratges que venessen o la valor d'açò que donassen ha d'altres persones"; afegint més endavant que de "altres erbes no saben que jamés sa'n donàs delma ne daguna part, ne aximateix onzè se'n dege donar ne'n darien".
} 
amb determinades quantitats de diners, mentre que, pel que fa a l'aviram, no es precisa la forma de pagament. També a Tamarit (1380) s'aplicava la taxa sobre anyells, cabrits i porcells. Per a altres animals es donaven les següents tarifes: $5 \mathrm{~s}$. per mul nascut o per bèstia cavallina; $2 \mathrm{~s}$. per ase $o$ somera, i igual quantitat per bou o vaca; però, es pagaria sols si l'animal sobrevivia als vuit dies del seu naixement. També es feien pagar $6 \mathrm{~d}$. per cada poll. A Constantí (1381), a més de la contribució establerta sobre la cria de cabres, ovelles, vaques, burres i truges, s'indica l'obligació de pagar $4 \mathrm{~d}$. per cada alberg o casa, pagament que es faria a compte d'una pollada de polls, anadons i ocons. A Alcover (1393) es cobraria dotzè de "xets" (anyells?), ovelles i porcs ${ }^{75}$.

En altres llocs es dóna també una casuística diferent. A Piera (1377), en el cas de tenir menys de deu cries ("nadons") es cobraria redelme del preu d'estimación ${ }^{76}$. Tot propietari d'una truja que tingués més de quatre cries o "porcells" en donaria un com a redelme; per menys de quatre, es faria pagar del preu d'estimació obtingut com hauran II meses passats. Per altra part, es pagaria una gallina per cada pollí (de mul o d'ase) i per cada vedella. A Moià (1378) s'havia de pagar un vintè de les cries d'animals petits, mentre que per als més grans es donava la següent contribució: $9 \mathrm{~d}$. per a les vedelles (potser extensiu a altres animals grans) i $12 \mathrm{~d}$. per cada porca amb cries. Pel que fa al comtat d'Urgell (1373) es mencionen diversos animals (vaques, someres, eugues, truges, polls, oques, ànecs) sobre els quals requeia un "delme semblant al delme comú segons és acostumat en cascun loch de les dites universitats a pagar". Posteriorment, a Agramunt (1391) es pagaria una onzena part del bestiar (axí de lana com d'altra natura), però si el nombre era inferior a onze, es cobraria una onzena part del preu d'estimació de tots ells. L'impost es pensava cobrar el maig, més concretament lo dia de Santa Creu. A la baronia de Bellpuig (1457) es faria pagar impost per cada porca que parís un porcell per any, el qual havia de tenir un mes o cinc setmanes de vida. Cada casa dedicada a la cria de polls donaria un exemplar a canvi si no de pagar $8 \mathrm{~d}$., sempre segons la preferència del recaptador. Pel que es refereix a animals grans, s'estipula la mateixa contribució que regia a compte del delme: de somerí, $4 \mathrm{~d}$.; de mula

\footnotetext{
${ }^{75}$ "rellevat ço que costarà ho ço que se estimarà al dia que.s farà la stima e ço que valrà més al dia que.s matarà, que pach de ço que més valrrà lo XIIè".

${ }^{76}$ Aquest redelme es pagaria en realitat com un onzè, ja que més endavant es fa el següent aclariment: "de onze nadons ne paguen un de reedelme".
} 
i bou, $8 \mathrm{~d}$.; i de cavall, $1 \mathrm{~s}$. Quan el lliurament de l'impost es feia en espècie, els recol-lectors podrien tenir els animals dins del terme sense pagar res, tal com apareix indicat a Santa Maria del Pla (1380) i a Agramunt $(1391)^{77}$.

En altres localitats, els propietaris de bestiar havien de fer una declaració de tot el que tenien en el moment en què el recaptador es fes càrrec del cobrament de l'impost. A Valls (1394) els jurats elegirien dos homes experts per a dur a terme la valoració del bestiar (a càrrec, però, de l'arrendatari). Al cap de l'any tornaria a valorar-se i es cobraria del benefici que s'hagués obtingut, és a dir, de les transaccions realitzades amb aquells animals. Tothom restava obligat, doncs, a informar sobre les operacions de compra/venda realitzades amb el seu bestiar i a declarar-ne el preu pel qual l'havia comprat o venut ${ }^{78}$. En el cas de no ser venut durant l'any, es faria pagar després d'haver realitzat una segona estimació, de tal manera que l'onzè s'aplicaria sobre l'estimació que resultés més alta. De fet, en aquest cas es tractava de contribuir més pels guanys obtinguts del bestiar (segons el que comentarem més endavant) que per la cria mateixa, encara que això tampoc sembla descartar-se ${ }^{79}$. Per altra banda, es feia contribuir segons la participació en el negoci ramader (ja fos que el ramat es tingués a terz $o$ a miges, o a qualsevol part, com s'indica a Valls), o bé a qui tingués al seu càrrec bestiar pertanyent a persones de fora vila.

-Productes ramaders: llana, formatges, mel.

La llana, tal com s'indica a Piera (1377), es feia pagar en vellons. A Agramunt (1391) es pagaria l'onzena part de la llana el dia que s'esquilava el bestiar, prohibint de treure-la abans de què es personessin els recaptadors, els quals tenien plena opció per escollir els vellons que volguessin emportar-se. La llana es posava en una muntera coberta amb una

\footnotetext{
77 "que puxen tenir tots los bestiars que hauran del dit onzè en los termes de la dita vila e en los erbatges e emprius de aquella, en tota aquella partida que plaurà als dits compradors sens alcun càrrech, salari o paga o altre dret que algú pogués demanar; e açò hun any complit despuix que'l hauran oncenat cascun any".

${ }^{78} \mathrm{La}$ contribució per la compra de bestiar també és present en els capítols de Reus (1388), incidint gairebé en els mateixos aspectes que a Valls.

${ }^{79} \mathrm{~A}$ més del que ja hem explicat, pagaria onzè "tot hom (...) qui haurà (...) de ses egues et someres, vaques, ovelles o cabres o truges, nadiços", però quan fossin venuts; $\mathrm{i}$, si no es venien, serien igualment valorats pels dos prohoms designats a fi de poder contribuir segons el preu d'estimació.
} 
tela (gonega) segons ja s'acostumava a fer a propòsit del cobrament del delme. A Valls (1394), en canvi, es faria pagar l'onzè de la llana al cap de vuit dies després d'haver finalitzat l'operació d'esquilada.

Respecte als formatges, es tracta d'un altre producte que apareix mencionat en els capítols de manera bastant corrent. A Santa Maria del Pla (1380) es donarien tants formatges com es pagaven a l'arquebisbe i al paborde, sense precisar-ne el nombre. A Valls (1394) es pagaria onzè d'aquest producte cada quinze dies.

Però, a més dels referits productes, l'impost també podia recaure sobre altres activitats productives, com l'apicultura. Es feia pagar sobre els productes derivats, com s'indica a Valls (1394): mel, cera i cerut. Per això, calia declarar totes les arnes que es tinguessin (les cases d'abelles, com es diu algun cop), puix que, en el cas de què la mel o la cera no fos venuda, aquesta seria estimada i es pagaria en relació al valor d'estimació. Així mateix, a Alcover (1393) es podia cobrar en cera o en mel, segons la preferència del collidor de l'impost.

-Peix

El peix apareix mencionat en algunes poblacions marítimes, com Mataró (1391) i Tamarit (1394). En aquesta última localitat no es cobraria el dret sobre el peix destinat al consum propi, sinó tan sols del peix que es vengués, és a dir, una vegada més, pel guany obtingut. En general, concerneix una activitat que ja apareix contemplada implícitament en l'apartat relatiu als guanys.

\section{c) Rendes}

Qualsevol tipus de rendes, tant si es cobraven en diner com en espècie (i, especialment, els censals $i$ violaris) estaven subjectes a contribució. A Cervera (1381), com hem dit amb anterioritat, la forma de taxació era distinta, ja es tractés de censals (gravats amb un 7,5\%), violaris (5\%) o censos $(10 \%)$. Posteriorment, s'aplicaren altres taxes: un dotzè $(8,3 \%)$ concernent a tot tipus de rendes (el 1414); i un deè (10\%) el 1439. Respecte als cabals s'aplicaria una taxa (en aquest cas, un 7,5\%) com si es tractés de censals, és a dir, sobre un hipotètic fruit o interès estimat al $10 \%$.

Pel que es refereix únicament als censals/violaris, l'impost es cobrava de l'annual o pensió, independentment del lloc on es percebien: a Reus (1388), per exemple, es donava un termini de 6 dies per a pagar l'onzè 
$(9,09 \%)$ després de rebre la pensió. Per altra part, el contribuent tenia fixat un altre termini per a manifestar al recaptador de l'impost tots els censals que rebia. A Valls (1394) s'indica quelcom semblant, encara que el termini per a pagar-lo era major: concretament d'un mes. A Alcover (1393) es feia pagar un dotzè $(8,3 \%)$ sobre tots els censals percebuts dins el terme, tant si incumbia habitants de la vila com forasters, i sols un $4,16 \%$ per als censals percebuts fora del terme, segons el criteri que ja s'aplicava a tota classe de béns.

En algun cas també es contempla la contribució dels lloguers de cases: així, a Constantí (1381) es faria pagar un deè (10\% per tant) a tots els perceptors d'algun lloguer. A Alcover (1393) es mencionen els lloguers de vivendes, així com els arrendaments de terres o collites (possessions a splets), aplicant-hi la taxa del $8,3 \%$.

\section{d) Guanys i salaris}

És en aquest últim apartat on resideix el caràcter més novedós de l'impost, o sigui, pel fet d'aplicar-se sobre tot tipus de guanys, àdhuc dels artesanals. Així, els productors artesans havien de contribuir pels guanys obtinguts de la venda dels seus productes. Com es diu a Constantí, per al cas dels sabaters: per vendre sabates, no importa on, encara que la contribució era a compte, no pas de la venda, sinó del guany que s'hagués fet. Alguns capítols (com els pertanyents a Reus, Valls i també Constantí) són especialment interessants pel fet de voler especificar tots els possibles menestrals que podien estar subjectes a contribució, d'on obtenim un quadre molt divers de totes les activitats pretesament realitzades en aquelles localitats. Des d'aquest punt de vista, es tracta de dades que fins a cert punt poden reflectir les especificitats de l'estructura econòmica de cada vila.

L'impost requeia, doncs, sobre diversos sectors productius: del tèxtil, de la pell, de la fusta, del metall, de la construcció, etc. En principi, no es podia escapar a l'impost res que generés algun tipus de guany. També calia contribuir per treballs artesanals realitzats en l'àmbit domèstic: així, pel que respecte a certes labors tèxtils, com filar ${ }^{80}$. Els artesans estaven

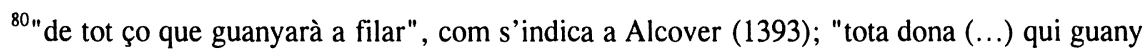
astemenejar lana ne a filar, ne encare del li, ne de qualque obrasvulla" (Reus/1388). Cal tenir en compte que les dones també són referenciades en oficis del ram del tèxtil (sastresses, teixidores, ordidores) o bé com a forneres, flequeres, taverneres...
} 
obligats a donar compte de tots els guanys obtinguts durant la setmana al finalitzar aquesta ${ }^{81}$. El cobrament es faria, doncs, els caps de setmana i en el lloc indicat pels jurats ${ }^{82}$.

Per altra part, els petits comerciants (especiers, mercers, tenders) havien de contribuir pels guanys obtinguts de totes les transaccions realitzades. En general, es faria pagar per guanys de qualsevol mercaderia comprada o venuda, tal com s'indica a Valls ${ }^{83}$. Inclús els revenedors de certs productes ("d'obra de palma, d'obra de cera, de peix salat") havien de contribuir per igual raó. A Reus (1388) dels guanys obtinguts de cereals, llegums o oli, s'aplicaria la taxa vigent en el moment de l'operació ("levat lo for que valrà en la vila aquell dia"), de manera que es pagaria onzè del resultant, després de descomptar-hi els drets pertinents, com eren les lleudes i les imposicions.

La taxa s'aplicava sobre el muntant de diner percebut. A Alcover (1393) es pagaria el 8,3\% de tots els guanys obtinguts dins el terme: és a dir, de cada 12 diners, un. A Cervera $(1381 ; 1414)$ es dóna la particularitat de què els guanys, per exemple dels petits comerciants, serien estimats prèviament al $10 \%$ independentment de què guanyessin més o menys; i sobre aquesta estimació s'aplicava la taxa indicada, que era del 7,5\%; i així mateix pel que respecte als comerciants de draps (drapers).

En tots els casos indicats fins aquí hem d'entendre que no es pagava per la transacció mateixa, sinó pel guany obtingut. De fet, la manera com s'expressen alguns capítols pot induir a cert grau de confusió en aquest aspecte. A Valls mateix (1394) s'inserta un capítol en virtut del qual es feia contribuir als fabricants o productors de draps a raó d'1 diner per alna (mesura de longitud equivalent a 1/2 metre més o menys) "vulles obs de casa o per vendre", la qual cosa fins a cert punt suposaria una assimilació amb

\footnotetext{
${ }^{81}$ Per exemple, a Constantí (1381) s'indica que "tota persona del dit loch e terme que dels dits oficis o guanys usarà o farà, que lo digmenge haja a retre compte al dit colidor de ço que la setmana aurà guanyat (...), e que li haja a donar son dret".

${ }^{82}$ Com s'indica a Valls (1394): "de tot ço que haurà guanyat dins la setmana que.u haja a dur a l'onzener en aquella taula hon los jurats assignaran".

83 "tot hom (...) qui compra o vena deguns blats grossos o menuts, de legums, frutes, mensura, oli, mell, cera, fusta, sèu, lana, ayns, flaçades, literas, capçals, pellices, bonetes, ferre, acer, coure, calderiz obrat o obrar, cànem, li, e totes altres coses, mercaderies que.s compren ni.s venen" etc.
} 
altres formes d'imposició sobre les quals, de tota manera, el municipi no tenia cap competència ${ }^{84}$.

Tractant-se de mercaderies i de productes artesanals, es cobraria del guany obtingut un cop feta la deducció d'altres drets: lleudes, generalitats o imposicions segons el cas. Així, encara que sigui de manera indirecta, a partir dels capítols d'aquest impost obtenim una radiografia molt completa (almenys en certs casos) de totes les activitats sobre les quals concorrien altres formes de tributació ${ }^{85}$.

Però a més dels artesans i mercaders, també estaven subjectes a contribució els carnissers, forners, taverners, moliners, etc. A Alcover (1393) els forners havien de declarar cada diumenge tot el que haguessin guanyat durant la setmana ("e quant la somada que aurà mòlta serà acabada de vendre"). A Valls (1394) els propietaris de forns tenien prohibit de treure el pa del forn mentre el recaptador no hagués percebut l'impost. Quant als hostalers, a Cervera (1414) es taxava el 5\% dels seus guanys; sols estaven subjectes a gravamen els llits del servei, però no pas els de propi ús. Semblantment, a Alcover (1393) els hostalers pagarien "de ço que guanyarà en la civada e en la palla".

A part de tots aquells autònoms que basaven el seu modus vivendi en els guanys obtinguts del seu propi negoci, n'hi havia que havien de contribuir a compte de les retribucions que rebien d'altres. Dit d'una altra manera, en aquest impost contribuïen també els assalariats. A Cervera (1381; 1414) els salaris dels notaris (així com també dels savis) es taxaven a raó del $5 \%$, i estaven obligats a declarar tots els seus guanys. En altres localitats (Constantí, Reus, Valls) també es tenien en compte els guanys de notaris, escrivans o savis, aplicant la taxa elegida en cada cas.

Per altra part, també contribuïen els recaptadors de rendes (excepte, com ja s'ha indicat, els de la senyoria) i els recaptadors de talles o de

\footnotetext{
${ }^{84}$ Aquesta forma d'imposició tenia molta similitud amb el cobrament de les generalitats, impost que era administrat per l'òrgan emanat de les Corts i que gravava la circulació de draps. No és extrany, doncs, que capítols com aquest poguessin ser motiu de censura per part dels oficials reials que inspeccionaren la forma com havien estat aplicats aquests impostos per les poblacions del Camp; sobre aquesta qüestió, vegeu J. MORELLó, La problemàtica d'un impost cit., pp. 249-282.

${ }^{85}$ Així, quan es fa referència als guanys obtinguts a partir de la comercialització de draps, s'esmenten les generalitats com a dret detractiu: "qui vena drap de lana, ni de li ni de cànem, que levat leuda, generalitat, dret de sagell" (Constantí/1381). En tots els altros casos que es refereixen als guanys d'artesans i comerciants es mencionen tan sols les lleudes i les imposicions.
} 
col·lectes d'altra índole, tal com s'indica a Constantí (1381): "tota persona (...) que plech censals ni rendes de quisvol les plech, ni deutes, ni per procuració haja res, ne en qualsevol manera que guany res, ne plech talles, malles ni neguns diners, ni blats, ni vi, ni oli"; o de forma semblant a Valls (1394): "qui plegarà censals, violaris, talles de regines o d'altres drets, o regiran procuracions", etc. També estaven subjectes a contribució les persones que exercien oficis més o menys vinculats amb el municipi, segons l'indicat a Valls el 1394 (guardians, joglars, savis i faulequers) on, d'altra banda, s'eximia de contribució el salari dels jurats.

En el grup d'assalariats també cal incloure els servidors domèstics. A Alcover (1393) tota persona que guanyés algun salari com a missatgé o serventa havia de contribuir cada tres mesos. A Valls (1394) s'indica com a única excepció el calçat i el vestit que se'ls donava en caràcter de manutenció. Naturalment, l'impost sols es podria cobrar durant el temps que coincidia amb el període de vigència del mateix, tal com es té cura d'indicar a Valls i en altres llocs.

Dins d'aquesta àmplia gamma d'activitats gravades, també s'incloïen els jornals dels transportistes. A Alcover (1393) s'aplicava la taxa corresponent sobre els guanys obtinguts pels carreters dins el terme, tant si eren habitants del lloc com si eren forasters, mentre que, pels guanys obtinguts fora del terme, calia pagar (només referit, naturalment, als habitants) $3 \mathrm{~d}$. per cada dia i per cada carga, si el transport es feia amb muls, rocins o eugues, i 2 d. si es feia amb ases o someres. El cobrament, com en tants altres casos, es faria cada diumenge.

Seguint en la mateixa línia, podem dir que l'impost requeia igualment sobre tot tipus de treball agrícola: "qui.s loch a cavar ne a podar, ne a laurar, ne a traginar ne altra faena a fer" (Constantí/1381). Pel que es refereix al conreu de les terres, es cobraria independentment dels diferents sistemes de contratació, ja fos a preu fet, a jornals o a quarterades, com s'indica en els capítols de Reus-Valls-Constantí, en molts aspectes similars. En general, qualsevol mena de labor era susceptible de ser gravada amb aquest impost, com els indicats a Constantí (1381): "qui.s loch a tapiar, ne a cobrir, ne a sotspedrar, ne a lavar, ne a solar, ne a fer neguna faena que sia acostumat de fer". Finalment, també els materials utilitzats en la construcció eren considerats com a matèria contributiva: a Valls (1394) s'havia de pagar per la producció de calç i guix, i també per la fabricació de teules, rajoles i toves. A l'igual que en altres casos, si no es venien en el període indicat, s'aplicaria l'onzè sobre el preu d'estimació. 


\section{FORMA DE PERCEPCIÓ: TRETS GENERALS}

Després de passar revista a l'àmplia gamma de productes gravats i de veure les particularitats que es donen en cada cas, serà convenient d'intentar definir les característiques principals o més comunes tocant a la forma de percepció, encara que sigui incidint en aspectes ja comentats, i abans també de prosseguir amb altres qüestions.

Respecte al lloc i moment de percepció, l'impost, com ja hem vist, podia ser obtingut en el mateix lloc on es feia la collita i immediatament després de satisfer els drets senyorials ("aprés que'ls dits fruits seran delmats e primiciats", com es deia el 1373 en el comtat d'Urgell), o bé al cap d'un cert temps, quan es tractava de collites obtingudes fora del terme. La declaració també podia fer-se en el moment en què la collita era venuda, o encara quan era introduïda a la vila, com en el cas de la verema. El pagament es faria aleshores en els llocs designats pels dirigents municipals ("taules"). Malgrat tot, una mateixa collita sols podia ser gravada una sola vegada, ja fos que es taxés en el moment de la recol·lecció o bé després de ser venuda ${ }^{86}$. Ja hem vist també que en certs casos el pagament havia d'anar precedit d'una valoració de béns i/o de la corresponent declaració als recaptadors de l'impost dels guanys obtinguts durant la setmana per la realització de qualsevol tipus d'activitat productiva. Per altra part, la taxa havia de ser aplicada íntegra, sense que es pogués fer cap tipus de desgravació, sense poder excloure, per tant, la llavor destinada a la sembra ${ }^{87}$.

Respecte a la forma de pagament (en espècie o en diner), ja hem vist que en principi es feia pagar en espècie, sempre que el producte no fos objecte d'alguna transacció, puix que aleshores es cobraria en relació amb el preu de venda. Un cas diferent era el bestiar, ja que es podia prendre en espècie o en diner, segons les capitacions convingudes. De fet, aquesta

\footnotetext{
${ }^{86}$ Per exemple, a Tamarit (1380) aquesta qüestió apareix indicada reiteradament: "Emperò, que aquell blat que conreerà, si lo ven, que no sie tengut de pagar dotzè altra vegada"; etc.

${ }^{87}$ Tal com es deia a Agramunt (1391) per al cas de les collites: "lo qual XIè hajan a donar franchament, pure e neta, axí que no'n puguen levar ne deduir res per lavor ne per messions, ne per delma ne ventim, ans hajan a comptar en la dita onzena part la dita delma que pagada hauran, si aquella ja serà pagada o no"; o, com a Vilaverd (1404): "sens deducció de despeses e lavor"; o de forma similar a Valls (1394), però per al cas dels guanys dels fusters i altres menestrals: "que del guany que.y farà, levat lo preu pur que li costarà, haja pagar l'onzè a l'onzener, que no.n puxen ésser abatudes degunes messions d'obradures ni per nenguna altra manera". Aquesta advertència serveix, en general, per a tots els supòsits contemplats.
} 
qüestió també estava a la discreció dels mateixos recaptadors, com hem anat veient en diferents ocasions, ja que -en cas d'optar pel cobrament en espècie- aquells podien prendre la part de la collita que preferissin: qual part se vulran del munt, tal com apareix indicat a Tàrrega (1377) per al cas dels cereals, o també per al cas de la verema: vulles primera, mijana $o$ derrera, la qual cosa pressuposa que el cultivador feia les munteres i el recaptador es quedava amb la muntera de la seva elecció. En canvi, per al cas de la verema, aquesta podia ser taxada cada any pels administradors de l'onzè, i en aquest cas, es pagaria en diner.

Tractant-se d'un impost sobre les collites, el cobrament s'amotllava, naturalment, al calendari agrícola, de manera que es feia pagar després d'haver fet la valoració de cada tipus de collita: per exemple, a Tàrrega (1377) la collita del blat seria preuada (aforada) a la festa de santa Maria d'agost; la de la verema, a Tot Sants; i, la del safrà, a sant Andreu (30 de novembre). A Reus (1426), el cereal es prendria el mes d'agost, després de la batuda, i, la verema, després de la recol-lecció del setembre, o sigui, per Tot Sants. Els procediments eren similars a tot arreu, sempre en funció dels cicles productius de cada cultiu. Evidentment, el nivell de sostracció de l'impost (un cop fixada la taxa) estaria molt condicionat per les fluctuacions de les collites d'aquell any ${ }^{88}$. Això era un factor tingut en compte en alguns casos: a Constantí (1381) hi havia interès perquè el deè de les olives es cobrés l'any de bona collita ${ }^{89}$. Si un any era especialment dolent, es podia posposar el cobrament en espera d'anys més fructífers ${ }^{90}$.

Per tal de tenir un control sobre la producció, s'obligava als contribuents a declarar als recaptadors tots els seus guanys, així com totes les transaccions realitzades amb aquells béns subjectes a l'impost segons els capítols establerts a cada localitat. A Tàrrega (1377), per exemple, es deia que cada singular havia de manifestar cada any quant de safrà, cereals 0

\footnotetext{
${ }^{88}$ Els coetanis atribuïen les irregularitats de les collites a la voluntat divina, amb expressions com ara: "...que cuillaran e déu los darà en les primeres vinents messes e en les primeres vinents venemes" (Moià/1377) o "de tots los fruyts que déus darà" (Agramunt/1391), etc.

${ }^{89} \mathrm{Hom}$ tenia en compte l'alternança de collites bones i dolentes: "com en aquest any sia stada anyada d'olives, l'any vinent no deguen ésser, com una anyada aprés altra no sia".

${ }^{90}$ La universitat d'Alcover obtingué el 1456 del vicari de l'arquebisbe una dispensa respecte del pagament d'un dotzè durant un any a causa de la carestia (propter temporum sterelitatem); però la mateixa dispensa fou obtinguda per segon cop al cap d'un any i per la mateixa raó, sia, davant la persistència de la carestia; AHAT, RN (1454-56), fols. 162 v.-163 r. (12-V) 1457-59, fol. 37 r. (22-VI).
} 
verema havia collit aquell any. De tota manera, era el propi municipi qui assumia l'operació d'estimar aquests béns. A Valls (1394) calia denunciar al collidor de l'onzè tot el vi que es treia fora del terme, mentre que l'estimació havia de ser feta pels jurats ${ }^{91}$. A Cervera (1414) s'assenyala l'obligació de declarar o manifestar tot allò que estava sotmès a l'impost; altrament dit, sobre certs productes o rendes calia fer una estimació prèvia per a poder-hi aplicar la taxa corresponent ${ }^{92}$. Tot i així, roman sempre el dubte de saber si (com creia Max Turull per al cas de Cervera) s'utilitzaven els mateixos llibres de manifest - registres que servien de base a la taxació de les talleso la recaptació de l'impost comportava realitzar algun tipus de registre especial. En contra d'això últim hi juga el fet que no s'ha conservat, que sapiguem, cap registre de béns declarats en vistes a satisfer un onzè o similars. Sigui com vulgui, les estimes (manifests, valies, etc.) constituïen almenys un referent, tal com es fa explícit en alguns casos. A Valls, segons els capítols de 1394, per a totes aquelles persones que no fossin incloses en els llibres d'estima o bé fossin considerades de poca valia, o encara els conversos (potser perquè es tractava d'un nou col-lectiu de contribuents que no havia "tingut temps" per ser incorporat a una operació general d'estimació de la població local), es nomenaria una comissió per tal de decidir la forma d'efectuar el pagament de l'impost. En altres llocs, com a Reus (1388), s'obligava a donar constància dels canvis de propietats, la qual cosa es justificava perquè els fruits obtinguts d'aquestes propietats estaven subjectes al pagament de l'impost en qüestió. Considerant, doncs, que molts municipis tenien costum d'utilitzar llibres d'estimes o de manifests per a les taxacions de les talles, i on apareixien també anotats tots els béns mobles sotmesos a la contribució de les talles, no els feia falta confegir registres a part que haurien comportat més aviat una duplicació innecessària. Un cas distint seria la confecció de registres per anotar la recaptació de l'impost, almenys quan els collidors eren nomenats pel propi municipi ${ }^{93}$.

\footnotetext{
${ }^{91}$ També en el cas d'aplicar-se sobre el consum de vi, seria el propi recaptador qui prendria compte de les existències que cada singular tingués, pero fixem-nos que sols es refereix a la denúncia o "manifest" i no a la valoració del producte.

${ }^{92} \mathrm{Ja}$ el 1379 el Consell cerverí deia de fer una crida perquè tothom manifestés de nou els mobles i les rendes, justificat perquè l'onzè no es podia taxar bé si, doncs, no es feia un nou manifest d'aquells béns; cf. M. TURULL, La configuració cit., pp. 524.

${ }^{93}$ L'arxiu de Cervera és, que sapiguem, l'únic que conserva documentació referida al cobrament d'impostos sobre la renda, segons les recerques dutes a terme per Pere Verdés. I s es conserva és justament per la raó indicada. De tota manera, la forma de gestió més habitual
} 
Així, doncs, l'estimació dels béns mobles subjectes a l'impost posa en evidència l'estreta relació que hi havia entre els onzens i les talles, tot $\mathrm{i}$ les diferències existents en la forma de percepció. De tota manera, la pràctica fiscal sovint esdevé força complicada pel seu caràcter heterogeni, amb tendència a agrupar o aparellar formes d'imposició de diversa naturalesa i fins al punt que de vegades es fa difícil destriar, per a l'actual investigador, un impost de l'altre. Vist així, no ha d'estranyar la creació d'alguns impostos híbrids que, a més, són exponents de la creativitat fiscal de l'època. A Tàrrega (1377) s'ideà un procediment mixte i fins a cert punt original segons el que expliquem a continuació: tenint en compte el muntant del capital dels censals i de les pensions que havia de pagar la universitat, es preveia imposar una qüèstia o talla anual durant un període de 6 anys. Tots els habitants de la vila que fossin taxats en aquesta qüèstia pagarien una onzena part de les seves collites (de només tres productes: blat, verema i safrà). Això no obstant, la contribució es faria per via de qüèstia ("a sou e a liura"). El que resultés d'aquesta taxació es confrontaria amb les pagues de l'onzè commutades en diner: si resultava que s'havia contribuit per més, aquest sobrant es posaria a compte de la paga de l'any següent; si resultava, en canvi, que s'havia contribuït per menys, caldria que el contribuent hi addicionés dels seus béns per la part que faltava ${ }^{94}$. Aquest procediment, però, resultà anar en perjudici dels més pobres, com es deia un temps després, ja que, si el pagament de l'onzè sobre les collites requerides no arribava a la quantitat per la qual el contribuent havia estat taxat segons la qüèstia, tal contribuent o pagès hauria de satisfer la part de menys de la seva mateixa collita ${ }^{95}$. Tal procediment suposa, doncs, un intent d'adequar aquest impost a les talles, i potser no seria una pràctica del tot excepcional. Aquest és, de fet, el sistema que veiem aplicar més tard en algunes poblacions del Camp de Tarragona sota el nom de milanar, una modalitat impositiva que a partir del segon quinquenni del segle XV substituí als onzens pròpiament dits.

Ben bé es tracta d'un impost híbrid, ja que es taxava de la mateixa manera que les talles (prenent de base els llibres d'estimes), però es cobrava

a tot arreu seria l'arrendament, d'aquí el caràcter excepcional de la documentació al.ludida.

${ }^{94} \mathrm{Cf}$. Ll. SARret, Privilegis de Tàrrega, p. 302.

${ }^{95} \mathrm{Cf}$. Ibidem, p. 308, en nota. 
en espècie i sobre determinats productes, com en els onzens precedents ${ }^{96}$. Les disposicions del 1426 concernents a Reus indiquen que la recaptació dels milanars establerts aleshores es basava en les estimacions fetes per al conjunt de la població, les quals havien de ser anotades en el nou registre que es pensava fer: "segons les vàlues que cascun haurà en lo manifest novell de la vila"97. En tot cas, ens referim a un impost que s'aparta de la forma de percepció més original i específica del que hem anomenat impost sobre la renda.

A banda, la recaptació d'aquests milanars (en principi cobrats en espècie) donà peu a un funcionament del tot particular. El procediment, segons el que observem a Valls durant el segle XV a propòsit de la percepció dels "milanars de blat", era el següent: al principi de la recol·lecció el municipi establia quin havia de ser el pagament en espècie, o bé en diner. Així, es podia fer pagar mitja quartera de blat per milanar, que, a raó, per exemple, de 6 sous per quartera, suposava pagar 3 sous per milanar (o sia, $3 \mathrm{~s}$. per cada $1.000 \mathrm{~s}$. d'estimació), si és que es preferia contribuir en diner. El cereal s'emmagatzemava a la botiga del blat, i passat un cert temps es procedia a vendre'l als mateixos habitants, per la qual cosa era necessari establir el "for" o preu de conversió, variable cada any. El diner obtingut d'aquestes vendes s'emprava - o tal era la intenció manifestada- en l'amortització de censals, amb la qual cosa es mantenia la mateixa finalitat comesa als onzens precedents ${ }^{98}$. Podem veure, doncs, que la recaptació de l'impost acabà vinculant-se amb l'administració del blat ${ }^{99}$.

De fet, l'àmbit d'aplicació de l'impost tendí a restringir-se a aquells productes dels quals s'esperava obtenir majors rendiments, com era el cas

\footnotetext{
${ }^{96} \mathrm{El} \mathrm{nom} \mathrm{de} \mathrm{"milanar"} \mathrm{deriva} \mathrm{de} \mathrm{les} \mathrm{taxacions} \mathrm{de} \mathrm{les} \mathrm{talles:} \mathrm{o} \mathrm{sia,} \mathrm{de} \mathrm{les} \mathrm{taxes} \mathrm{"per} \mathrm{milanar"}$ en virtut de les quals es feia contribuir a un tant per cada mil sous de la riquesa que es declarava.

${ }^{97} \mathrm{~A}$ banda de les estimes també es feien servir llibres de talla, o sigui, on devien figurar les taxacions de cada contribuent, exactament igual que en el procés de recaptació d'una talla. Així, cadascú havia de pagar un "milanar" (en aquest cas sobre el cereal i la verema) segons l'anotat en el llibre de la talla: "...que tot hom que sia taxat en los dits millenars (...) haja a paguar segons taxat serà en lo libre de la talla".

${ }^{98} \mathrm{~A}$ Tàrrega, ja el 1377 , es preveia que, del diner obtingut de la venda dels productes sobre els quals requeia l'onzè (cereals, verema o vi, i safrà), descomptant-hi salaris i totes les despeses fetes en la col.lecta i en la mateixa venda, es fessin les redempcions de censals que els administradors estimessin més oportunes; cf. Ll. SARreT, Privilegis de Tàrrega, p. 304.

${ }^{99} \mathrm{Per}$ a més informació, consulteu J. MORELló, Fiscalitat $i$ finances cit., cap. 5.3.2. de la Primera Part, p. 584 i ss.
} 
dels cereals, la verema i el safrà, l'oli, i no gaires més. En algunes localitats (almenys d'aquelles de les quals tenim informació corresponent a diferents èpoques $\mathrm{i}$, per tant, $\mathrm{amb}$ referents anteriors per poder inferir l'evolució de l'impost) podem observar una progressiva reducció del ventall de productes sotmesos a l'impost a només uns quants, ben segur seguint criteris de rendibilitat. A Reus, per exemple, al llarg del segle XV s'imposaren "milanars" tan sols sobre tres productes: de "blat" sobretot, de verema $\mathrm{i}$ d'oli. A Valls es va recórrer regularment a "milanars" de cereals i, que sapiguem, sols de cereals. Això contrasta amb l'ampli ventall que es dóna en els capítols que hem presentat de finals del segle XIV per a aquestes mateixes localitats. Per regla general, en les concessions del segle XV el ventall contributiu apareix més simplificat que no pas al XIV. Encara que caldrà estudiar-ho amb més deteniment, sembla que l'impost sobre la renda anà identificant-se cada vegada més amb un impost específicament agrari, cosa que implicava prescindir de gravar altres productes o altres tipus de guanys. Aquesta tendència s'hauria accentuat encara més en època moderna. Es pot pensar que la percepció d'aquests impostos va resultar difícil i problemàtica: difícil per als recaptadors, els quals havien de comptar amb ajudants per a poder estar presents en tots els moments i a tots els indrets on s'havia de cobrar l'impost; i, problemàtica, puix que seria relativament fàcil realitzar fraus, segons el que exposem a continuació.

Efectivament, la possibilitat de defraudar apareix contemplada, amb major o menor émfasi, en bastants dels capítols que hem disseccionat fins al moment. Evidentment, les formes de frau són similars, si no idèntiques, a les que es donaven en el cobrament dels delmes senyorials ${ }^{100}$, per exemple, en l'ocultació de part de la collita o quan es retirava el blat de l'era abans que es personés el recaptador ${ }^{101}$; o en el fet de no declarar tots els guanys obtinguts; etc.etc. Així s'explica l'èmfasi que es dóna a la forma concreta

\footnotetext{
${ }^{100}$ Vegeu G. Feliu, ob. cit., pp. 40-41.

${ }^{101} \mathrm{~A}$ Reus (1426), a propòsit del "milanar del blat", s'indiquen en quines úniques circumstàncies es permetia que el pagès s'emportés el cereal a casa seva quan el recaptador no acudia a l'era: "és axí entés que com alscú ho alscuns tindran lo blat en la era et hauran denunciat al dit collidor que vingue prendre son dret, e per ventura ell no.y volrà venir o no.y porà venir, si aquell die serà bell e clar ho serà e farà senyals de pluja, si serà bell e clar que tot lo die lo haja a tenir en la dita era tro al sol post e post lo sol que'l se'n puxa portar a sa casa; et, si feya temps plujós, que lladonchs, feta la fadigua, lo sol post no sperat, lo se'n puxa portar a sa casa; et despuys, axí aquell que per temps plujós com aquell que per rahó de la nit lo se'n haurà portat, lo hajen a pagar al dit collidor tota ora que ell lo volrà; sinó, que li puxa fer tancar la porta entrevenint-hi lo manament del senyor".
} 
de percebre l'impost, segons el que hem anat exposant fins aquí. Per al cas del cereal, si es delmava en garba (i ja hem vist que això era el més usual), el frau era més difícil, puix que calia emportar-se necessàriament les garbes a l'era per tal de fer la batuda. Però, la forma de defraudar seria deixar a la muntera ("grapissos") quant més gra millor, de manera que pogués ser recuperat quan el delmador hagués marxat ${ }^{102}$. En el cas del safrà (i també del roldor) seria més fàcil cometre frau una vegada el cultivador s'emportava a casa seva el safrà per a assecar-lo, atés el caràcter poc voluminós d'aquest producte. En el cas de la verema, es sancionava el fet d'introduir-la a la vila d'amagat i sense passar pel control pertinent. Com es deia a Cervera (1414): "si alcú per frau o ocultament en amagada metrà venema en la dita vila sens que no sie scrita e denunciada als dits portals..." En els mateixos capítols es feia al-lusió a d'altres procediments fraudulents; per exemple per no declarar totes les rendes i censals percebuts o no dir tota la veritat, segons l'indicat en altres casos.

Per raons òbvies, un dels col·lectius més propensos a sostraure's al pagament de l'impost era el dels forasters que obtenien collites dins el terme. Així mateix, les activitats realitzades pels mateixos habitants fora del terme serien difícilment controlables. Per altra part, ja hem fet al·lusió a la prohibició de traspassar béns (per exemple, rendes) a les persones privilegiades, fet que era vist com una estratagema per a sostraure aquests béns al pagament de l'impost. No cal dir que el frau estava sancionat severament: amb la pèrdua de la collita i/o el pagament d'una multa (diferent en cada cas), a més d'haver de contribuir segons l'estipulat.

\section{FORMA DE GESTIÓ}

El municipi podia optar per arrendar l'impost (mitjançant subhasta pública) o per dur a terme la col-lecta directament mitjançant la designació d'uns recaptadors $^{103}$. Si s'arrendava, podia ser conjuntament o per separat,

\footnotetext{
${ }^{102}$ Sobre aquestes qüestions, vegeu G. FELIU, ob. cit., pp. 40-41.

${ }^{103}$ Per exemple, a la parròquia de Badalona (1388) foren designades set persones com a recol.lectors; ACA, C, reg. 1893, fols. 91 v. -92 v. i reg. 1898, fol. 90 r. i ss. A Moià (1378) s'elegiren també set persones, però en aquest cas per a encomanar el vintè o bé arrendar-lo "ensemps o de partida (...) en cars que fer se pusque, axí com dit és"; ACA, C, reg. 1683, fols. $103 \mathrm{r} .-104 \mathrm{v}$
} 
segons les conveniències dels dirigents municipals. El cert és que en determinats casos resultava més beneficiós arrendar l'impost globalment a una o més persones, però de tal manera que l'arrendatari assumís ell mateix el pagament o amortització de les pensions dels censals. Per exemple, l'onzè establert a Tàrrega (1377), malgrat que en un principi s'havien nomenat tres regidors (onzeners) perquè el collissin i l'administressin, acabà arrendant-se a un ciutadà barceloní, el qual es comprometé a redimir fins a $27.430 \mathrm{~s}$. de capital de censals/violaris i a pagar, mentrestant, les pensions corresponents durant quinze o setze anys (en lloc dels sis inicialment previstos), i a canvi també de què la universitat li donés cada any certa quantitat $(12.000 \mathrm{~s}$.) en caràcter d'ajuda ${ }^{104}$. En altres llocs s'actuà de forma similar, almenys pel que fa a l'arrendament de tot el conjunt de l'impost. A Cervera, el mateix any de 1377 s'arrendava tot l'onzè a un barceloní pel preu de $3.600 \mathrm{ll}$. (72.000 s.) pel període d'un any ${ }^{105}$. A Agramunt (1391) es féu un pacte amb dos notaris i un mercader barceloní, els quals es comprometien a fer-se càrrec del pagament de les pensions dels censals, així com de la seva amortització durant un cert temps ${ }^{106}$. Com es veu, la menció de barcelonins en aquestes operacions no és quelcom fortuït, sinó que ens indica clarament quin era el centre urbà on era més fàcil trobar inversors prou solvents. També en diverses poblacions del Camp de Tarragona es varen fer pactes sobre el conjunt de l'impost: a Valls (1394) l'onzè acabà arrendant-se a un veí de la Riba pel preu de 33.000 s. ${ }^{107}$; a Santa Maria del Pla (1380) s'arrendaren les collites de 12 anys a dos ciutadans de Tarragona (no hem vist indicat per quin preu); i a Alforja (1393) s'arrendaren a tres persones pel modest preu de $6.000 \mathrm{~s}$. (3.000 a l'any).

De fet, allò que resulta més sorprenent és que aquests tractes podien fer-se amb els mateixos creditors del municipi. Així, a Agramunt (1391) els creditors s'encarregarien de percebre l'impost a canvi d'una sèrie de

${ }^{104} \mathrm{Cf}$. Ll. SARret, Privilegis de Tàrrega, p. 308, en nota.

${ }^{105} \mathrm{Cf}$. M. TURULL, La configuració jurídica cit., p. 525.

${ }^{106} \mathrm{Cf}$. MaT. FERRER, art. cit., p. 398. El termini prescrit era de 17 anys. De fet, la major part dels capítols es refereixen a les condicions de l'arrendament. En un cas, per exemple, s'indicava que si per causa de guerra no es podia prendre l'onzè íntegrament, els dits arrendataris quedaven dispensats de pagar les pensions o de redimir censals, cosa que aniria a compte de la universitat. En aquest cas, el termini seria prolongat durant tot el temps que no s'hagués pogut recaptar l'impost.

${ }^{107} \mathrm{AHCV}$, Llibre del Consell (1393-96), fol. 30 v. I això malgrat l'expressat en els capitols del mateix any, on en principi es preveia realitzar arrendaments de cada producte per separat. 
facilitats, segons l'indicat en les corresponents capitulacions signades amb el municipi, i sobre les quals no cal entretenir-se en aquest moment. A la baronia de Bellpuig (1457) es convingué amb els creditors de totes les universitats que en formaven part a satisfer un onzè als recaptadors designats per aquells ${ }^{108}$.

Ultra això, altres vegades era el mateix senyor local qui es feia càrrec del pagament de les pensions a canvi de percebre l'impost, la qual cosa podia tenir conseqüències no desitjades. Això succeí a Mollerussa (1419), on, segons Gaspar Feliu, la població transferí al senyor el cobrament de l'impost de manera perpètua a canvi que es fes càrrec de diverses pensions de censals que devien per un total de 700 lliures $(14.000 \text { sous })^{109}$. Aquest fet ocasionà problemes en el futur, en ser assimilat a una exacció senyorial, és a dir, a partir de quan ja s'havia oblidat quin havia estat l'origen d'aquell impost ${ }^{110}$.

En qualsevol cas, el procediment més usual seria arrendar els diferents productes subjectes a contribució de forma separada, tal com també se solia fer amb les imposicions ${ }^{111}$. Els ingressos obtinguts per aquesta via podien consignar-se junt amb els altres ingressos municipals o bé generar una comptabilitat específica, tal com tenim constatat en el cas de Reus ${ }^{112}$. En efecte, en aquesta localitat veiem actuar a finals del segle XIV i durant el segle XV un clavari com encarregat de rebre els diners dels onzens (després, dels milanars) amb els quals es realitzava l'amortització dels censals. Així, els arrendataris s'entenien directament amb el responsable

\footnotetext{
${ }^{108} \mathrm{El}$ capital de totes les pensions que es pagaven sumava més de 21.000 II., una quantitat enorme tractant-se de petites poblacions; vegeu R. MIRÓ, art. cit., pp. 13-36.

${ }^{109}$ Cf. G. Feliu, ob. cit., p. 137.

${ }^{110} \mathrm{El} 1397$ es habitants de Montsonís cediren, segons sembla, al comte d'Urgell un onzè per 20 anys, segurament per tal que es fes càrrec dels deutes que tenia la població. Ja al segle XVI s'originà un plet que durà fins al segle XIX i en el qual el senyor pretengué percebre'l considerant que es tractava d'una prestació senyorial, mentre que els habitants d'aquell lloc la consideraven una exacció il.legal; vegeu J. FERNÁNDEZ / Ll. CODERN, El castell de Montsonís, Lleida, 1994, p. 57 i ss. (existeix una versió en castellà: El castillo de Montsonís, Lleida, 1995, p. 62).

"'A Reus, per exemple, ens consta que durant el 1388-89 i les següents anyades es varen fer, per regla general, sis arrendaments diferents més o menys en funció amb l'establert en els capítols del 1388: l'onzè dels blats, l'onzè del vi (i la verema), l'onzè de l'oli, l'onzè del roldor. l'onzè dels censals (i menuderies) i l'onzè dels guanys (informació detallada a J. MoRELLó, Fiscalitat i finances cit., vol. 2, Apèndixs, p. 280).

${ }^{112}$ Pel cas de Manresa, en els anys posteriors al 1416 es veu actuant un receptor o administrador del diner de l'onzè; AHCM, Manual del Consell, 1416-22, s.f.
} 
d'aquesta clavaria, qui actuava seguint les directrius dels magistrats municipals. Aquesta clavaria desapareixia quan deixava de recaptar-se l'impost en qüestió i reapareixia quan de nou s'encetava un altre període de col-lecta.

El cert és que el jurats estarien temptats d'utilitzar aquesta font d'ingressos en altres usos diferents als estipulats amb les autoritats. Sols excepcionalment, el senyor podia consentir la satisfacció puntual d'altres despeses que no fos pagar els deutes dels censals. Evidentment, una feina que resta per fer a cada localitat serà sopesar la importància financera d'aquesta font fiscal en relació amb altres ingressos fiscals ${ }^{113}$.

\section{CONSIDERACIONS FINALS}

Podem plantejar-nos, finalment, si aquest impost podia ser, a la llum de les dades aportades fins aquí, més just o equitatiu que les talles. Pel que concerneix a les collites, és obvi que, si aquestes havien estat dolentes, es pagaria menys, i que, en el cas contrari, es pagaria més, sempre depenent de la proporció escollida. Certament, en tant que gravava directament la producció, suposaria fer contribuir segons el que realment es guanyava i no sobre un conjunt de béns que en part podien ser improductius ${ }^{114}$. Com es deia a Moià (1378), a propòsit de l'establiment d'un vintè, això era "la pus covinent talla que fer podien, com, qui més haurà, més hi metrà". Era, des d'aquest punt de vista, un impost realment ajustat al nivell productiu de les economies domèstiques. El fet era que, mentre que una talla es taxava sobre béns tant productius com improductius, un onzè afectava només els béns productius. Aquesta diferenciació no existeix, en canvi, quan s'intentava

\footnotetext{
${ }^{113}$ Aquesta qüestió està fora de les nostres possibilitats més enllà del que sabem de les dues localitats (Reus i Valls) directament estudiades a la nostra tesi: J. MorELLÓ, Fiscalitat $i$ finances cit., pp. 979-980 i 1090-1091. Pel cas de Reus, l'existència d'una administració específica per aquest impost explica els pobres resultats obtinguts dels llibres de clavaria. Amb tot, des del punt de vista financer, no sembla que es tractés d'ingressos massa importants, una impressió que també tenia Max Turull per al cas de Cervera; cf. M. TuRULL, La configuració cit., p. 526.

${ }^{114}$ Des d'una perspectiva actual s'entén que si únicament es gravés el patrimoni, el resultat seria una reducció paulatina fïns que arribaria un moment en què tal patrimoni no seria capaç de produir rendes suficients per a la subsistència de l'individu. Vist així, era molt més "intel-ligent" l'aplicació de talles sobre la renda en sí mateixa, que era el que veritablement generava o sustentava la riquesa de cada persona.
} 
cobrar un onzè taxant-lo com una talla, tal com succeí a Tàrrega. Recordem que en aquesta localitat aquest procediment fou considerat perjudicial per part dels sectors més desafavorits per les raons ja indicades. Amb tot, una altra avantatja d'aquest impost era la possibilitat de contribuir en espècie, cosa que resultava menys onerós per part d'alguns sectors que d'altra manera es veurien obligats a comercialitzar la collita per a poder satisfer l'impost en diner, que era la forma de pagament de les talles repartides segons una quantitat precisa per cada contribuent. En tot cas, l'establiment d'impostos d'aquest tipus sembla haver suscitat reaccions molt diverses segons en quin lloc o en quin moment. A Lleida, per exemple, l'intent d'establir un "onzè" el 1366 (probablement per primera vegada) comportà una ferma oposició per part d'alguns sectors de la població (llauradors i menestrals), els quals es consideraven molt agraviats, fins al punt que, davant les dificultats trobades, es va haver de suspendre la recaptació i optar per la via de la talla ${ }^{115}$. En qualsevol cas, no podem passar per alt el fet que l'establiment d'aquest impost suposava una sobrepunció fiscal, sobretot en aquelles localitats on es va imposar de forma extensiva a tota mena de productes, i sobretot perquè s'afegia al pagament d'altres impostos municipals (talles, imposicions) o bé extramunicipals, com les lleudes i les generalitats, a més, naturalment, de les detraccions senyorials ja conegudes (delmes, primícies) i, en algun cas també, de les tasques.

L'establiment d'una taxa sobre la producció podia provocar l'abandó dels cultius per tal d'eludir el pagament de l'impost. Així s'indicava a Agramunt (1391), on, pel que sembla, la situació devia ser molt preocupant. Els dirigents d'aquest municipi instaven als terratinents a cultivar les terres que tinguessin dins del terme per tal que la universitat pogués percebre l'impost; si, a pesar d'això, no ho feien, haurien de contribuir com si les

\footnotetext{
"Aixi, davant les dificultats que hi va haver per la percepció d’aquest "onzè" (del qual, però, no s"indica, a la nostra font d’informació, sobre quins productes es va imposar) els magistrats de la ciudat convocaren alguns llauradors i representants dels oficis per a explicar-los les causes per les quals havien decidit establir un impost d'aquest tipus. El rebuig per part dels llauradors fou total, ja que alguns respongueren que preferien morir abans que contribuir en aquell impost. En qualsevol cas, l'intent, per part de l'oligarquia, d'aconseguir el recolzament d'altres capes socials i el consegüent rebuig. almenys en la forma com es volia establir. no donà resultat pel seu caràcter altament impopular: "com lo poble per res consentirà a la via de l'onzè": Arxiu de la Paeria, Consells Generals, reg. 400 (1366-67), fol. 2 r. i ss. (agraïm a Manuel Sánchez aquesta informació).
} 
haguessin conreat ${ }^{116}$. I si, per altra part, hi havia algú que canviava de domicili i passava a residir en una altra vila, seguiria pagant l'impost de tot el que cultivés a qualsevol terme durant tot el temps que durava el contracte que s'havia signat amb els creditors o perceptors de l'impost.

Tot $\mathrm{i}$ les característiques generals observades, aquest impost municipal es troba a mig camí entre la fiscalitat senyorial i altres formes impositives municipals, fins al punt que podia arribar a confondre's amb un dret senyorial, és a dir, en el cas de què la població hagués transferit al senyor la responsabilitat en el pagament del deute municipal a canvi de cobrar l'impost - segons el que ja hem vist plantejat en el cas de Mollerussa-, fet que comportaria la seva perpetuació, si és que mai no s'arribava a descobrir el seu veritable origen.

En alguns llocs potser es deixaria de percebre definitivament davant una millora de la situació financera, o simplement perquè l'evolució de les finances municipals seguí uns altres camins. En alguns llocs, en canvi, es continuà percebent fins, que sapiguem, al segle XVIII ${ }^{117}$. Pel que fa als segles posteriors, la percepció d'aquest impost — prenent de base alguns estudis realitzats per modernistes- sembla circumscriure's a un àmbit més restringit, ja que es documenta en localitats situades en zones primordialment agràries $\mathrm{i}$ en certa mesura allunyades dels principals circuits comercials, $\mathrm{i}$ com impost exclusivament agrari, ja que resten fora de tributació les rendes, els guanys artesanals i els salaris. En certa manera, es podria pensar que aquest impost sobrevisqué en aquells llocs on l'Antic Règim seguí mantenint un sistema de producció genuïnament feudal i en contrast amb l'expansió de l'economia capitalista que es produí a les ciutats i viles de major dinamisme econòmic i comercial del país. Però, com tants altres, constitueix una altra

\footnotetext{
${ }^{116}$ El capítol en qüestió diu el següent: "per tal com vuy se fá gran menció que molts homens fora lo terme conrehen dins lo dit terme e, si per aventura d'aquí avant per rahó del càrrech del dit onzè o en altra manera, los hòmens qui vuy conrehen dins lo terme no volien conrear, que la dita universitat sie tenguda de fer conrear aquella part que cessaven de conrear, la qual vuy s’acostuma de conrear; e, si no.u fayien, que sien tenguts de pagar lo onzè de ço que hi poria ésser si.s conreave a coneguda de dos prohòmens elegidors la hú per los dits cullidors e l'altre per la dita universitat".

${ }^{117}$ L'estudi de Gaspar Feliu sobre la comarca de l'Urgell és el més complet, però hi ha altres treballs ja citats referits a d'altres comarques, com l'Ampurdà ( $P$. Gifré), o que aporten notícies a d'altres localitats, com Granollers (J. Dantí); Móra d'Ebre i Gandesa (E. Badosa), sobre les quals, en canvi, no tenim cap noticia a la percepció d’impostos d'aquest tipus en èpoques anteriors al 1500 .
} 
qüestió que caldrà estudiar a fons. Es tracta, si més no, d'un tema que interessa tant als medievalistes com als modernistes. 


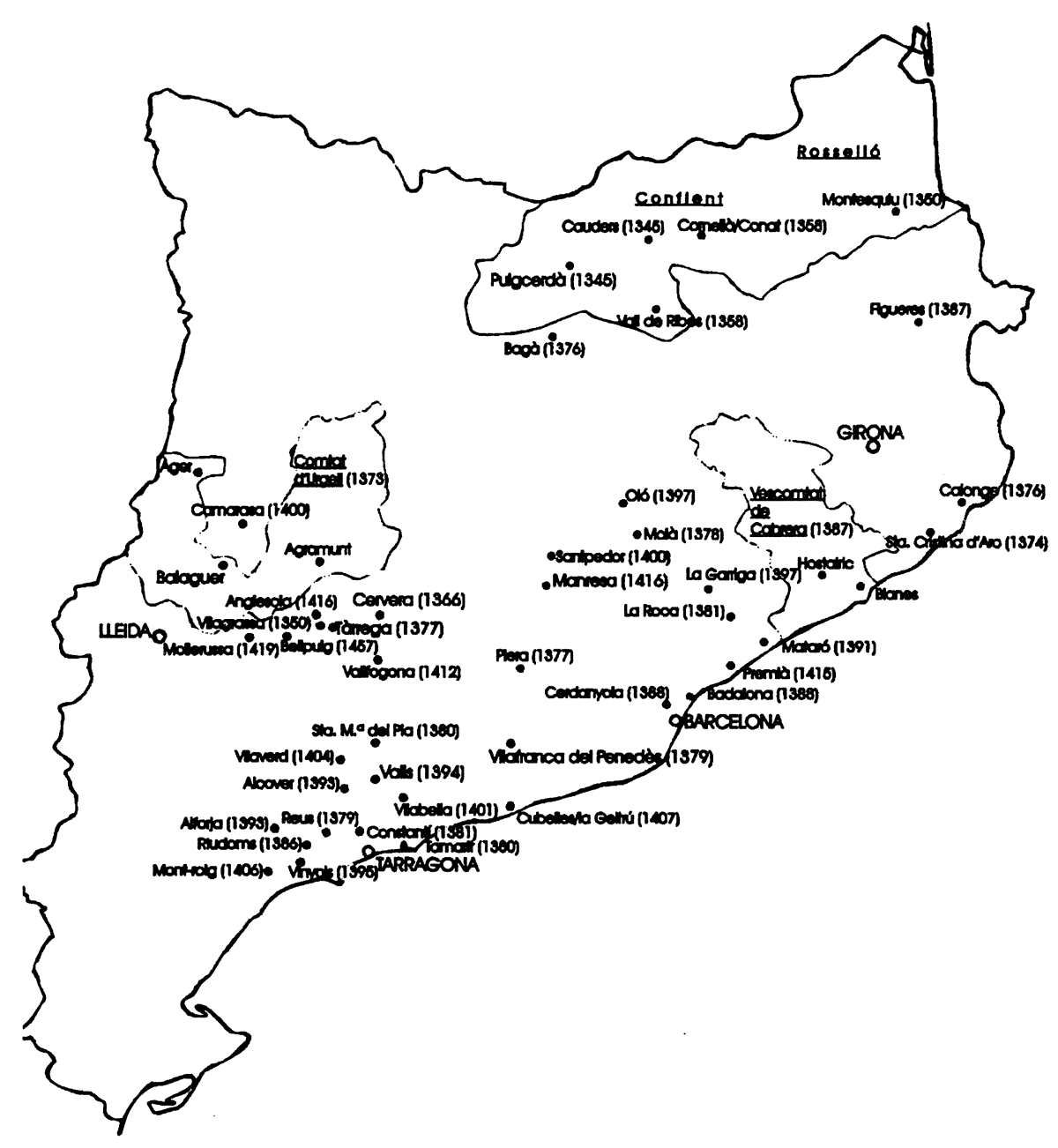




\section{ANNEXES}

\section{TAules}

Productes gravats segons els capitols de l'impost (correlatiu al llistat B)

\begin{tabular}{||l|l||}
\hline Lloc & Tàrrega \\
\hline Any & 1377 \\
\hline Atorgant & rei \\
\hline Durada & 6 anys \\
\hline Taxes o denominació & Onzè \\
\hline Productes gravats & blats, verema, safrà \\
\hline
\end{tabular}

\begin{tabular}{||l|l||}
\hline Lloc & Piera \\
\hline Any & 1377 \\
\hline Atorgant & rei \\
\hline Durada & 6 anys \\
\hline Taxes o denominació & Redelme \\
\hline Productes gravats & $\begin{array}{l}\text { hlats menuts i grossos, verema, roldor, olives, } \\
\text { nous, avellanes, cànem, lli, cebes, alls, cols, por- } \\
\text { ros: censals/violaris, rendes, censos, bestiar } \\
\text { (porcells, pollins...); guanys; llana, formatge; } \\
\text { safrà, glans, llegums. }\end{array}$ \\
\hline
\end{tabular}




\begin{tabular}{||l|l||}
\hline Lloc & Moià \\
\hline Any & 1378 \\
\hline Atorgant & Infant Joan \\
\hline Durada & 1 any \\
\hline Taxes o denominació & Vintè \\
\hline Productes gravats & $\begin{array}{l}\text { blat (forment) i verema; llana i nadissos de bestiar } \\
\text { menut i gros; moltures de molins i puges de forns: } \\
\text { censals/violaris, rendes: safrà; oli; guany de mer- } \\
\text { caderies i de menestrals. }\end{array}$ \\
\hline
\end{tabular}

\begin{tabular}{||l|l||}
\hline Lloc & Santa Maria del Pla \\
\hline Any & 1380 \\
\hline Atorgant & arquebisbe de Tarragona \\
\hline Durada & 12 anys \\
\hline Taxes o denominació & Dotzè/redelme \\
\hline Productes gravats & $\begin{array}{l}\text { blats, llegums; verema: olives: lli, cànem; safrà; } \\
\text { verdures/hortalisses: llanes, formatges; nadissos: } \\
\text { aviram: farratge. }\end{array}$ \\
\hline
\end{tabular}

\begin{tabular}{||l|l||}
\hline Lloc & Tamarit \\
\hline Any & 1380 \\
\hline Atorgant & probablement l'arquebisbe de Tarragona \\
\hline Durada & 12 anys \\
\hline Taxes o denominació & Dotzè \\
\hline Productes gravats & $\begin{array}{l}\text { blats, verema, olives, nadissos (anyells, cabrits, } \\
\text { de porcs i de bèsties grosses, polls...); llana i } \\
\text { formatges; hortalisses i verdures (alls, cebes, } \\
\text { cols, porros), llegums, lli, cànem; obra de pal- } \\
\text { ma; censals/violaris; rendes (quarts, quints, } \\
\text { tasca); guanys de mercaderies; salaris. }\end{array}$ \\
\hline
\end{tabular}




\begin{tabular}{||l|l||}
\hline Lloc & Cervera \\
\hline Any & 1381 \\
\hline Atorgant & Infant Joan \\
\hline Durada & 5 anys \\
\hline Taxes o denominació & Setzè, etc. \\
\hline Productes gravats & $\begin{array}{l}\text { verema/vi; censals/violaris, rendes; blats i esplets } \\
\text { en herba, safrà, oli, lli, cànem, faves i alls; } \\
\text { bestiar (cabrits, anyells i porcells) i llana: guanys } \\
\text { de botiguers, especiers i drapers; cabals i salaris. }\end{array}$ \\
\hline
\end{tabular}

\begin{tabular}{||l|l|}
\hline Lloc & Constantí \\
\hline Any & 1381 \\
\hline Atorgant & paborde de Tarragona (Seu vacant) \\
\hline Durada & 1 any \\
\hline Taxes o denominació & Deè \\
\hline Productes gravats & $\begin{array}{l}\text { blats grossos i menuts, llegums; farratge, veces, } \\
\text { panis, moresc; verema; bestiar (cabres, ovelles, } \\
\text { vaques, someres, truges); censals; salaris; llo- } \\
\text { guers; guanys diversos. }\end{array}$ \\
\hline
\end{tabular}

\begin{tabular}{||l|l||}
\hline Lloc & Riudoms \\
\hline Any & 1386 \\
\hline Atorgant & paborde de Tarragona (Seu vacant) \\
\hline Durada & 5 anys \\
\hline Taxes o denominació & Redelme \\
\hline Productes gravats & $\begin{array}{l}\text { blat, llegums, verema, olives i de totes menude- } \\
\text { ries. }\end{array}$ \\
\hline
\end{tabular}




\begin{tabular}{||l|l||}
\hline Lloc & Reus \\
\hline Any & 1388 \\
\hline Atorgant & senyoria (cambrer de Tarragona) \\
\hline Durada & $?$ \\
\hline Taxes o denominació & Onzè \\
\hline Productes gravats & $\begin{array}{l}\text { blats grossos i menuts, llegums; farratge i altres } \\
\text { herbes (veces, moresc, panís); roldor; fruites } \\
\text { diverses (...); verema (a més de panses, raïms o } \\
\text { agraç); olives: censals; salaris; guanys. }\end{array}$ \\
\hline
\end{tabular}

\begin{tabular}{||l|l||}
\hline Lloc & Agramunt \\
\hline Any & 1391 \\
\hline Atorgant & comte d’Urgell \\
\hline Durada & 17 anys \\
\hline Taxes o denominació & Onzè \\
\hline Productes gravats & $\begin{array}{l}\text { blats (forments, ordis, civades, avenes, espeltes, } \\
\text { mestall, mill, panissos, dacses); lli, cànem; safrà; } \\
\text { farratges; bestiars; llanes, verema. }\end{array}$ \\
\hline
\end{tabular}

\begin{tabular}{||l|l||}
\hline Lloc & Alcover \\
\hline Any & 1393 \\
\hline Atorgant & (arquebisbe de Tarragona) \\
\hline Durada & $?$ \\
\hline Taxes o denominació & Dotzè \\
\hline
\end{tabular}




\begin{tabular}{||l|l||}
\hline Productes gravats & $\begin{array}{l}\text { blats grossos i menuts, llegums; olives; verema; } \\
\text { menuderies (lli, cànem, alls, cebes, escalunyes, } \\
\text { fessols, cols, porros, llana, formatges, nadissos); } \\
\text { nodriments (xets, ovelles, porcs); guanys d'a- } \\
\text { belles; censals/violaris; guanys de forns/molins; } \\
\text { guanys de forners, flequers, hostalers, traginers; } \\
\text { salaris (de "logaders", "missatgers" o serventes); } \\
\text { lloguers d'albergs i arrendaments d'esplets; } \\
\text { guanys (ramaders, mercantils i artesanals). }\end{array}$ \\
\hline
\end{tabular}

\begin{tabular}{||l|l||}
\hline Lloc & Alforja \\
\hline Any & 1393 \\
\hline Atorgant & arquebisbe de Tarragona \\
\hline Durada & 2 anys \\
\hline Taxes o denominació & Dotzè \\
\hline Productes gravats & $\begin{array}{l}\text { blats, raïms, llegums, safrà, olives i altres es- } \\
\text { plets; bestiars }\end{array}$ \\
\hline
\end{tabular}

\begin{tabular}{||l|l||}
\hline Lloc & Valls \\
\hline Anys & 1394 \\
\hline Atorgant & arquebisbe de Tarragona \\
\hline Durada & $?$ \\
\hline Taxes o denominació & Onzè \\
\hline
\end{tabular}




\begin{tabular}{||l|l||}
\hline Productes gravats & $\begin{array}{l}\text { blats, vi, oli, roldor, cànem, lli, alls, cols, por- } \\
\text { ros, escalunyes, safanòries, cardo, nous, safrà, } \\
\text { farratge, panís, moresc, alfals, veces; bèsties } \\
\text { grosses i menudes; llana, formatges; nadissos; } \\
\text { abelles, mel, cera, cerut; calç, guix, rajola i teu- } \\
\text { les, coves; censals, soldades, guanys de forns i } \\
\text { molins; fustes, coures i escudelles; salaris de } \\
\text { procuracions; lloguers; guanys d'especiers, mer- } \\
\text { cers i tenders; guanys de sastres, paraires, teixi- } \\
\text { dors i flassaders; guanys de sabaters, blanquers, } \\
\text { cuiracers, barbers, hostalers, escrivans, savis, } \\
\text { febridors, coltellers, flequers, carders, manyans, } \\
\text { ferrers, pescaters, basters, arquejadors i corre- } \\
\text { dors. }\end{array}$ \\
\hline
\end{tabular}

\begin{tabular}{||l|l||}
\hline Lloc & Valls \\
\hline Any & 1402 \\
\hline Atorgant & arquebisbe de Tarragona \\
\hline Durada & 1 any \\
\hline Taxes o denominació & Vintè \\
\hline Productes gravats & $\begin{array}{l}\text { blats grossos i menuts; menuderies (olives, cà- } \\
\text { nem, lli, cols, porros, escalunyes, cardo; nadis- } \\
\text { sos, llanes, formatges); censals/violaris. }\end{array}$ \\
\hline
\end{tabular}

\begin{tabular}{||l|l||}
\hline Lloc & Vilaverd \\
\hline Any & 1404 \\
\hline Atorgant & arquebisbe de Tarragona \\
\hline Durada & 2 anys \\
\hline Taxes o denominació & Deè \\
\hline Productes gravats & blats, llegums, alls, cebes, cards; verema. \\
\hline
\end{tabular}




\begin{tabular}{||l|l||}
\hline Lloc & Cervera \\
\hline Any & 1414 \\
\hline Atorgant & rei \\
\hline Durada & 3 anys \\
\hline Taxes o denominació & Dotzè \\
\hline Productes gravats & $\begin{array}{l}\text { verema; censals i rendes; blats i esplets en herba } \\
\text { o farratges; oli; cànem, faves, alls, cebes i lle- } \\
\text { gums; safrà; bestiar (cabrits, anyells, porcells); } \\
\text { llana; guanys de mercaders, etc.; cabals i salaris. }\end{array}$ \\
\hline
\end{tabular}

\begin{tabular}{||l|l||}
\hline Lloc & Reus \\
\hline Any & 1426 \\
\hline Atorgant & cambrer de Tarragona \\
\hline Durada & 5 anys \\
\hline Taxes o denominació & Milanars \\
\hline Productes gravats & forment, vi, oli \\
\hline
\end{tabular}

\begin{tabular}{||l|l|}
\hline Lloc & Cervera \\
\hline Any & 1439 \\
\hline Atorgant & reina Maria \\
\hline Durada & 10 anys \\
\hline Taxes o denominació & Compartiment \\
\hline Productes gravats & verema; safrà; censals; guanys. \\
\hline
\end{tabular}

\begin{tabular}{||l|l|}
\hline Lloc & baronia de Bellpuig \\
\hline Any & 1457 \\
\hline Atorgant & comte de Cardona \\
\hline
\end{tabular}




\begin{tabular}{||l|l||}
\hline Durada & $?$ \\
\hline Taxes o denominació & Onzè \\
\hline Productes gravats & $\begin{array}{l}\text { blats grossos i menuts, verema, oli, safrà, lli, } \\
\text { cànem, faves, cebes, alls, dacsa, mill, panissos; } \\
\text { polls, pollins, porcells. }\end{array}$ \\
\hline
\end{tabular}




\section{LLISTATS}

A partir de la recerca realitzada conjuntament amb Pere Verdés hem aplegat diverses notícies relatives a l'establiment d'onzens, amb les quals hem confegit els llistats que oferim a continuació. Algunes de les dades exposades són inèdites $i$ altres obtingudes a partir de les referències que apareixen en obres publicades segons s'indica en cada cas. D'altra banda. només hem inclós les notícies pertanyents als segles XIV-XV però no les d'època posterior al 1500. Naturalment, es tracta d'un llistat provisional que podrà ser ampliat en el futur.

Sigles arxivístiques (únicament pel que fa a les fonts consultades directament): ACA $=$ Arxiu de la Corona d'Aragó; AHAT = Arxiu Històric de l'Arquebisbat de Tarragona (sèrie Registra Negotiorum = RN); $A H C M=$ Arxiu Històric Comarcal de Manresa; AHCR $=$ Arxiu Històric Comarcal de Reus; $\mathrm{AHCV}=$ Arxiu Històric Comarcal de Valls; AHPB

= Arxiu Històric de Protocols de Barcelona.

A. Concessions per poder percebre l'impost:

Alforja (Camp de Tarragona) i agregats (les Borges, els Banys i Tascals): 1393 (dotzè); Font: AHAT, RN (1392), fols. 18 v.-19 r.;

Badalona: 1388 (redelme); 1390 (ratificació de redelme); Font: ACA, C, reg. 1893, fols. 91 v. -92 v. i reg. 1898 , fol. 90 r. i ss.;

Balaguer (comtat d'Urgell i vescomtat d'Àger): 1373 (deè); Font: AHCBI, Llibre de Privilegis, fols. 2 r.-22 r. (informació subministrada per Pere Verdés);

Calonge: 1376 (delme o deè); Font: ACA, C, reg. 1681, fols. 169 r.-170 r.;

Cauders de Conflent: 1345 (redelme o vintè); Font: ACA, C, reg. 878, fols. 160 v.-161 r.;

Cerdanyola (Sant Martí de) i les Feixes (Sant Iscle de), parròquies: 1388 (redelme); Font: ACA, C, reg. 1894, fols. 57 r.-58 r.;

Cervera: 1377 ("nou dret"); 1381 (setzè); 1414 (dotzè); 1439 ("compartiment"); Fonts: [1377] ACA, C, reg. 929, fols. 67 v.-68 r.; [1381] AHCC, FM, Pergamins, 19-XII-1381; ibidem, 4-I-1414; [1414] ACA, C, reg. 3134, fols. 59 r.-v. i [1439] AHCC, FM, Actes i Negocis (1439-1454), fols. 64 r.-65 v. (menys la primera, tota la informació ha estat proporcionada per Pere Verdés); 
Cornellà del Conflent i Conat: 1358 (redelme, vintè, talles o altres exaccions); Font: ACA, C, reg. 900 , fol. 97 v.;

Figueres: 1387 (onzè); 1392 (onzè); Font: ACA, C, reg. 1890, fols. 83 v.-84 r. i reg. 1904, fols. 59 v. -60 r.; aquest últim apareix indicat a E. RoDEJA GALTER, Figueras. Notas históricas, Figueres, 1957, p. 22;

Garriga, la: 1397 (delme o altra part); Font: ACA, C, reg. 2295, fols. 15 r.-18 v.; cf. J. MAURI, Història de la Garriga, I. Barcelona, 1949, p. 150;

Mataró: 1391 (onzè o altra part); Font: ACA, C, reg. 1900, fols. 176 v.-177 v.;

Mont-roig (Camp de Tarragona): 1406 (redelme), Font: AHAT, RN (1406-07), caixa 6, n. ${ }^{\circ}$ 15a, fol. 30 r.-v.;

Montesquiu [Rosselló]: 1350 (vintè o redelme); Font: ACA, C, reg. 901, fol. 80 r.;

Oló i vall d'Aguiló: 1397 (redelme); Font: ACA, C, reg. 2189, fols. 62 v.-63 v. i també reg. 2166 , fol. 68 v. -69 r.;

Premià [parròquia]: 1415 (redelme); Font: ACA, C, reg. 2394, fols. 103 v.-104 r.;

Puigcerdà: 1345 (talla o redelme); 1361 (redelme); Fonts: ACA, C, reg. 878, fol. 226 v. i reg. 906 , fol. 141 r.-v.;

Reus: 1406 (onzè); AHCR, Comunitat de Preveres, carpeta 5, n. ${ }^{\circ}$ 5; parcialment transcrit a E. GorT, Pere de Luna i la senyoria de Reus, Reus, 1987, pp. 97-98;

Ribes, vall de (integra Queralbs, Pardines, Ribes, Planoles, Campelles, Ventolà, Bruguera i Fustanyà): 1358 (opció d'imposar un vintè, talla o redelme); 1376 (redelme o vintè); Fonts: ACA, C, reg. 900 , fol. 135 r. i reg. 1683 , fol. 43 r.;

Roca, la (integra diverses parròquies del Vallès: la Roca, Santa Agnès de Llerona, Òrrius, Vilanova i la vall de Riof / St. Sadurni de Ribes, St. Esteve de Vilanova, St. Andreu d'Òrrius, Sta. Agnès de Malanyanes i la dita vall): 1381 (redelme); 1417 (talla o redelme); Fonts: ACA, C, reg. 1686, fol. 111 v.-112 r. i reg. 1683, fol. 13 r.-v.;

Santa Cristina d'Aro i altres (Fenals, Romanyà de la Selva, Bellpuig = Bell-lloc d'Aro', Solius, al ducat i vegueria de Girona): 1374 (redelme); Font: ACA, C, reg. 925, fols. 216 v.-217 r.;

Santa Maria del Pla (Camp de Tarragona): 1401 (dotzè); Font: AHAT, RN (1401), caixa 6 , n. ${ }^{\circ} 14$, fols. 77 r. -78 r.; 
Vilabella (Camp de Tarragona): 1401 (dotzè); Font: AHAT, RN (1401), caixa 6, n. ${ }^{\circ} 11$, fols. 55 v. $-56 \mathrm{r}$.;

Vilafranca del Penedès: 1394 (redelme); Font: ACA, C, reg. 1909, fol. 34 v.:

Vilagrassa: 1350 (onzè); Font: ACA, C, reg. 891, fol. 14 r.

B. Capítols sobre la forma de percepció i/o condicions d'arrendament:

Agramunt: 1391 (onzè); Font: AHPB, Quartus Librus Venditionum, 1391-92 (notari Ponç Amorós), fols. 46 v. -52 v.; s'hi refereix $\mathrm{M}^{\mathrm{a}}$ T. FERRER MALLOL, El patrimoni reial i la recuperació dels senyorius jurisdiccionals en els estats catalano-aragonesos a la fi del segle XIV, "Anuario de estudios medievales", 7 (1970-71), p. 398;

Alcover (Camp de Tarragona): 1393 (dotzè); Font: ACA, C, Processos en foli, 114/5, fols. 14 r. $-18 \mathrm{r}$.;

Alforja (Camp de Tarragona): 1393 (dotzè); Font: ACA, C, Processos en foli, 114/7, fol. 13 r. i ss.;

Bellpuig d'Anglesola i altres llocs de la baronia dels Cardona (Sant Martí de Maldà, Vilanova de Bellpuig, Golmes i Castellnou de Seana): 1457 (onzè); cf.: R. MIRó, Pagar deutes, posar nous impostos. La riquesa dels insolvents poderosos, "Miscel.lània d'estudis. Economia, vida i societat", n. ${ }^{\circ} 9$, pp. 13-36;

Cervera: 1381 (dotzè); 1414 ("dotzè"); 1439 ("compartiment"); Fonts: segons supra (A);

Constantí (Camp de Tarragona): 1381 (deè); Font: ACA, C, Processos en foli, 114/9, fols. 14 r.-16 v.; transcrit a F. CoRTIElla, Història de Constantí. Constantí, 1981, pp. 202-207;

Moià: 1378 (vintè); Font: ACA, C, reg. 1683, fols. 103 r.-104 v.;

Piera: 1377 (redelme); Font: ACA, C, reg. 930, fols. 160 r.-161 r.;

Reus (Camp de Tarragona): 1388 (onzè); 1426 (milanars); Fonts: [1388] ACA, C, Processos en foli, 114/6, fols. 89 r.-103 r.; [1426] AHCR, Proveïments (ss. XIV-XVII), fulls diversos;

Riudoms (Camp de Tarragona): 1386 (redelme); Font: ACA, C, Processos en foli, 114/10, fols. 13 r.-14 v.;

Santa Maria del Pla (Camp de Tarragona): 1380 (dotzè); Font: ACA, C, Processos en foli, $114 / 4$, fols. 14 r.-16 v.; 
Tamarit (Camp de Tarragona): 1380 (dotzè); Font: ACA. C, Processos en foli, 114/2, fols. 16 v. -18 v.:

Tàrrega: 1377 (onzè); Font: ACA. C, reg. 930, fols. 152 v.-158 r. / Ll. SARRET I PONS, Privilegis de Tàrrega. Tàrrega, 1982, pp. 296-308;

Valls (Camp de Tarragona): 1394 (onzè); 1402-03 (vintens); 1470-71 (milanars) a part uns altres capítols de data desconeguda, però possiblement de 1454; Fonts: [1394] ACA, C, Processos en foli, 114/1, fols. 14 r.-33 v. i AHCV, "Llibre de l'onzè", fols. 17 r.-47 v., transcrit a J. MORELLÓ. La problemàtica d'un impost a finals del segle XIV: la imposició de l'onzè a Valls el 1394, "Miscel.lània de Textos Medievals", 8 (1996), pp. 249-282; [140203] AHCV. Llibre Gros, fols. 95 r.-101 v. (barrejat amb capítols d'imposicions): [1470-71] ibidem, fol. 204 r. (aquests últims reprodueixen els que atribuïm al 1454: ibídem. fols. 111 v. -112 r.):

Vilaverd: 1404 (dè̀); cf. F. CORTIELLA, Història de Vilaverd, Vilaverd, 1982, pp. 191-93.

C. Notícies diverses (sobre concessions, arrendaments, col.lectes, litigis, etc.):

Alforja (Camp de Tarragona): 1422 (milanar); Font: AHAT, RN (1417-22), c. 7, n. ${ }^{\circ} 16$, fols. 172 v. -173 r.;

Alcover (Camp de Tarragona): 1456/1457 (dotzè); Font: AHAT, RN (1454-56), c. 9, n. ${ }^{\circ} 23$, fols. 162 v.-163 r...; ibídem (1457-59), c. 9. n. ${ }^{\circ} 24$, fol. 37 r.:

Anglesola: 1416 (novè; anteriorment, un vuitè); cf. A. BACH I Riu, Història d'Anglesola, Barcelona, 1987, p. 67:

Bagà: 1376 (redelme); 1391 (vintè); cf. J. Serra VILARó, Baronies de Pinós i Mataplana, Barcelona, 1930, vol. 2, pp. 88-89;

Blanes i altres llocs del vescomtat de Cabrera: 1387 (deè); 1390 (deè); cf. J.M ${ }^{\text {a }}$ Pons GuRI, Llibre de la universitat de la vila de Blanes. Blanes, 1969, p. 124 i ss.;

Camarasa (marquesat de): 1400-01 (onzè); cf. M. ${ }^{a}$ T. Ferrer Mallol, El patrimoni reial.... p. 399;

Cervera: 1366 (delme); 1375 (onzè, ampliat el 1377), 1379 i 1380 etc.: cf. M. TURULL, La configuració jurídica..., p. 523;

Codony, el / Perafort: referència a un vintè sense indicar la data; cf. F. CoRTIELla, Notícies sobre el Codony, "Universitas tarraconensis", IV (1981-82), p. 150; 
Cubelles i la Geltrú: 1407 (quinzè): cf. J. COROLEU, Historia de Villanuela y Geltrú, Villanueva y Geltrú, 1878, p. 122: 1979², pp. 125-126 (Font indicada per l'autor: ACA, C. reg. 2048 , fol. 154 r.);

Linyola: 1373/1375 (redelmes); cf. E. MESTRE I RoIGÉ (coord.). Història de Linyola, Lleida. 1987. pp. 44-45:

Manresa: 1416 (onzè): Font: AHCM. Manual del Consell (1416-22), s.f.:

Mollerussa: 1419 (onzè): cf. G. Felıu. El funcionament del règim senyorial... p. 137:

Perafort: vegeu el Codony:

Perpinyà: 1311 (seixantè); cf. B.-J. ALART, Documents sur la langue catalane des anciens comtés de Roussillon et de Cerdagne. París. 1881. pp. 216-217:

Reus (Camp de Tarragona): 1379-81. 1388-1393 (arrendaments d'onzens): altres referències a col.lectes d'onzens en el període 1401-07; d'ençà aleshores s'imposaren milanars: 1407-13, 1416-17, 1426-31, 1434-44, 1471-74, 1479-80, segons informació extreta bàsicament del fons de Protocols notarials, a més de la documentació anotada més amunt (per a més detalls, consulteu la nostra tesi doctoral);

Santpedor: 1400 (redelmes): cf. Mn. A. VILA Y SAlA, Notícia històrica de la vila de Sampedor, Manresa, 1898, p. 261:

Vallfogona: 1412 (onzè); 1453 (mig onzè): cf. Mn. R. CoRBELla, Història de Vallfogona, Barcelona, 1975, pp. 76-79;

Valls (Camp de Tarragona): onzens (1393 i següents anys) / dotzens (a principis del s. XV) / posteriorment s’imposen milanars, constatat sobretot per al periode 1450-1475: Fonts: informacions extretes dels Llibres del Consell de 1393-1402, 1450-53, 1453-62 i 1472-74, i dels Llibres de clavaria de 1400/01, 1404/05, 1408/09, 1410, 1410/11, 1429/30, 1444/45 i 1457/58, a més de la documentació anotada més amunt (per a més detalls consulteu la nostra tesi doctoral);

Vinyols i els Arcs: 1395 (dotzè): Font: AHAT, RN (1395), caixa 4, n." 11, fols. 14 v.-15 r.;

Vilafranca del Penedès: 1379 (setzè); cf. J. VALLÈS I ALTRES (ed.), El Llibre Verd de Vilafranca, II, Barcelona, 1992, p. 582.

Resum original: 


\section{RÉSUMÉ}

L'auteur, spécialisé dans l'étude de la fiscalité municipale, analyse ici un type d'impôt particulier, que l'on convient d'appeler impôt sur le revenu ("redelmes", "onzens" et similaires). Il s'agit là d'un impôt spécial, qui présente des traits spécifiques par rapport à d'autres modalités fiscales mieux connues comme la taille et les impôts indirectes. Depuis la moitié du XIV ${ }^{e}$ siècle, il deviendra la troisième forme de ponction fiscale dans les municipalités catalanes. Plusieurs questions sont traités concernant cet impôt: comment est-il justifié; quelles raisons invoque-t-on pour l'établir, quand apparait-il; quelle est sa diffusion en Catalogne pendant les premiers deux siècles de son existence; est-il un impôt direct ou indirect; quels sont les sujets soumis à contribution, le cadre d'application, les taxes appliquées, les produits gravés; comment est-il perçû et géré. Les sources sur lesquelles s'appuie cette étude, tres vastes, concernent un nombre important de localités catalanes.

\section{SUMMARY}

The author, as an specialist in the study of municipal taxes, analyzes a sui generis tax, which is called tax on income (redelme, onzè, and so on). These taxes must be considered as a third type of tax control and are different from other taxes much better known such as talles and imposicions. The author describes the characteristics of these new taxes that levied in the municipalities by the middle of XIVth century and, at the same time, endeavours to clarify certain questions, such as how did these taxes appear and extend to the whole of Catalonia during the XIVth and XVth centuries; if they were direct or indirect taxes, who had to pay them, where they were collected, on which products were they imposed, etc. All these aspects are studied in the article over a wide number of records from the archives of catalan towns. The work is illustrated by a map and some lists made on the basis of hitherto unknown local records. 